Interfaces

Unharmonious Images Conceived by Troubled Minds: Graphic and Literary Caricatures in Heinrich Heine's French Affairs and French Painters

Vera Faßhauer

(2) OpenEdition Journals

Electronic version

URL: http://journals.openedition.org/interfaces/789

DOI: 10.4000/interfaces.789

ISSN: 2647-6754

Publisher:

Université de Bourgogne, Université de Paris, College of the Holy Cross

Printed version

Date of publication: 12 December 2019

Number of pages: 129-164

ISSN: 1164-6225

Electronic reference

Vera Faßhauer, « Unharmonious Images Conceived by Troubled Minds: Graphic and Literary

Caricatures in Heinrich Heine's French Affairs and French Painters », Interfaces [Online], 42 | 2019, Online since 12 December 2019, connection on 04 January 2021. URL : http://journals.openedition.org/ interfaces/789; DOI : https://doi.org/10.4000/interfaces.789

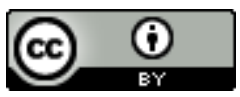

Les contenus de la revue Interfaces sont mis à disposition selon les termes de la Licence Creative Commons Attribution 4.0 International. 


\title{
UNHARMONIOUS IMAGES CONCEIVED BY TROUBLED MINDS: GRAPHIC AND LITERARY CARICATURES IN HEINRICH HEINE'S FRENCH AFFAIRS AND FRENCH PAINTERS
}

\author{
Vera Faßhauer \\ University of Frankfurt
}

\begin{abstract}
Although the German poet Heinrich Heine, who moved to Paris in 1831, repeatedly declared his commitment to a subjective and politically engaged way of artistic expression, he vehemently professed his dislike of the graphic satires which appeared in La Caricature and represented the "Citizen King" Louis Philippe in the shape of a pear. Nevertheless, Heine's own accounts of the current French Affairs for the German press exhibit many clear analogies to the seemingly detested satiric drawings: not only did he use them as an important vehicle of his own political criticism, but he also matched them with his own verbal caricatures of the French monarch and his cabinet. After showing that Heine and the caricaturists did indeed share the same butts and means of criticism, the article analyses both the graphic and verbal strategies and techniques they employed to avoid press censorship.
\end{abstract}

\section{Résumé}

Le poète allemand Heinrich Heine, qui s'était installé à Paris en 1831, déclara à plusieurs reprises son soutien à une expression artistique engagée et subjective, mais cela ne l'empêcha pas d'exprimer avec véhémence son aversion pour les satires publiées dans La Caricature, qui représentaient le « roi-citoyen », Louis-Philippe, sous la forme d'une poire. Cependant, les comptes rendus des affaires de la France envoyés par Heine à la presse allemande présentent bien des analogies avec les caricatures apparemment dédaignées. Il s'en servit pour renforcer ses propres critiques politiques, mais également en soutien à ses propres caricatures verbales du monarque et de son cabinet. Après avoir démontré que Heine partage les mêmes cibles et les mêmes procédés que les caricaturistes d'alors, nous analyserons les stratégies graphiques et verbales et les techniques utilisées pour éviter la censure de la presse. 


\section{Unequal Weapons? Verbal and Graphic Satire in Heine's Judgment}

Shortly after his move to Paris in May 1831, the German poet Heinrich Heine reviewed that year's Salon for the Morgenblatt für gebildete Stände, an influential German magazine edited by Johann Friedrich Cotta. ${ }^{81}$ Of all pictures exhibited, he showed himself most impressed by Alexandre Gabriel Decamps's Turkish Patrol (figure 1), which appeared to him like a coloured echo of his own heart's voice (DHA 12.1, 22). The small oil painting shows the Turkish police chief of Smyrna on horseback patrolling through a Christian city quarter in the company of nine armed men on foot. They are watched by four women who, wreathed with flowers, are standing at the windows and on the balcony of the sunlit building while the group is just hurrying past. The French art critics, Heine informs us, condemned this picture severely. Instead of striving for an objective imitation of nature and idealizing his subject, the artist caricatured his figures' features and represented them in a comic manner. Heine takes this opportunity to submit idealist aesthetics to a fundamental critique. Although idealism continued to predominate in both France and Germany, to his mind it was but a relic from the pre-revolutionary era. Still measuring contemporary art against the outdated standards of Greek and Roman antiquity, neo-classicism hindered the development of fresh artistic forms of expression. In times of political and social upheaval, to be precise, artists should critically deal with current events in an artistically adequate manner instead of secluding themselves from reality and creating ideal artificial worlds for their own sake. The new age, Heine believes, will also give rise to a new art in complete accord with it. Besides, the purpose of art was not the objectivizing imitation of outer nature but rather the subjective representation of the artist's inner thoughts (DHA 12.1, 47; Betz 11-29; Preisendanz 21-68). In this spirit, Decamps, too, had modelled his subject faithfully according to his own inner vision, and was therefore to be judged solely by his very own aesthetics which any critic had to accept. Moreover, the accusation of having caricatured his figures was easily disproved by the painting's harmonious colouring, which essentially depended on the artist's mental disposition and the consistency of his sentiments. Caricaturists, in contrast, suffered from a pathological incongruity of mind ("Gemütszerrissenheit"), which gave rise to their preference of the distorted and exaggerated over the beautiful and harmonious (DHA 12.1, 26). The paintings of William Hogarth, for instance, displayed nothing but coloured blotches screaming at each other and thus merely forming a turmoil of garish colours ("eine Emeute von grellen Farben)" (26).

"Gemütszerrissenheit" was a vogue word of Heine's day. It denoted an artist's conflicting sentiments considering the incompatibility of the ideal and actual reality, prompting him to pronounce

81 Heine's review of the "Gemäldeausstellung in Paris" (Exhibition of Paintings in Paris) appeared in October and November 1831 in the Morgenblatt and was republished under the title Französische Maler (French Painters) in 1834. 


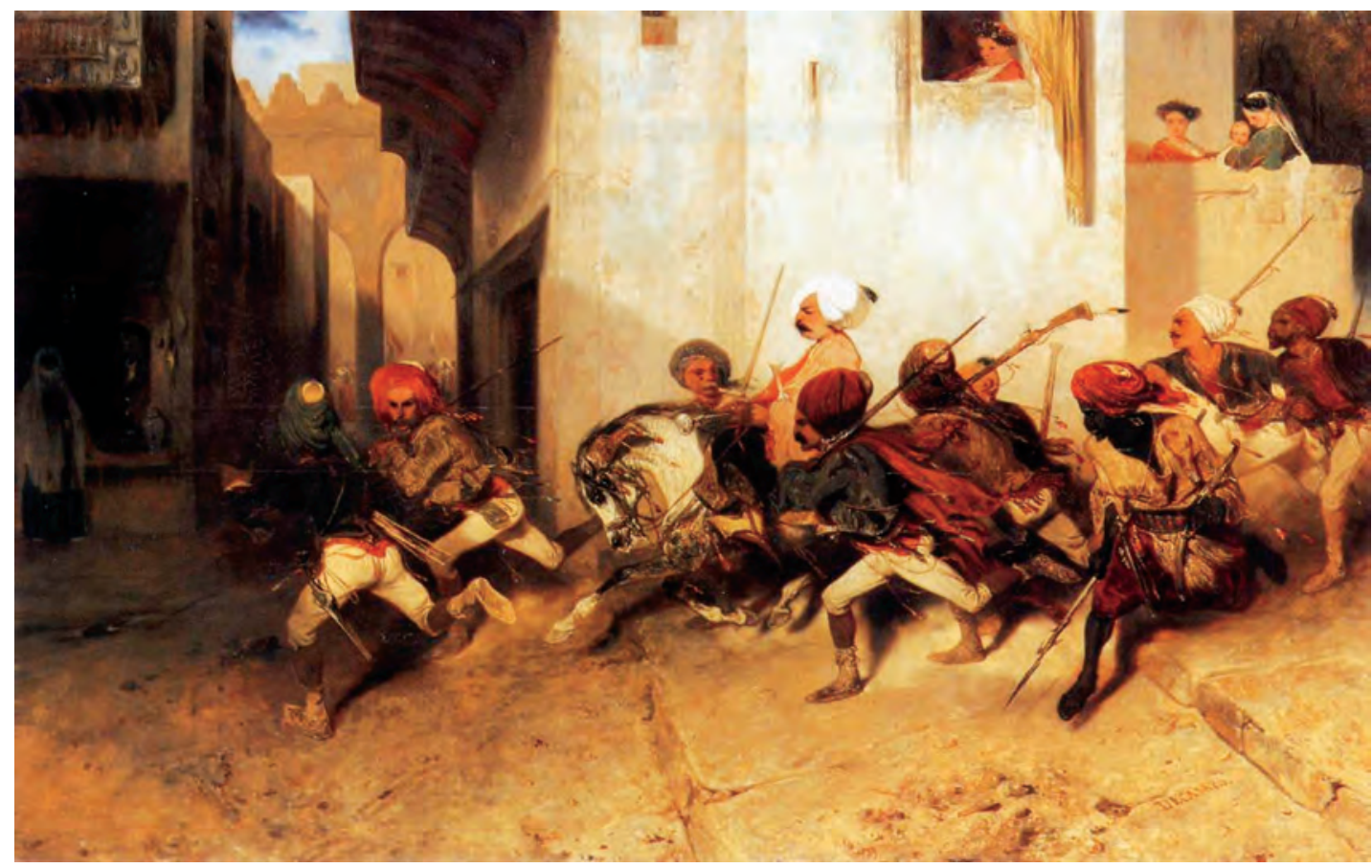

Fig. 1. Alexandre Gabriel Decamps (1803-1860), La Patrouille turque ou La Ronde du Cadjibey de Smyrne (Turkish Patrol or Round of the Hadji-Bey of Smyrna), 1831. Oil on canvas, 115 x $179 \mathrm{~cm}$. London, Wallace Collection. https://www.wga.hu/ art/d/decamps/t patrol.jpg

his subjective consciousness of social or political discrepancy (Rosenkranz 175-76; Vischer, Aesthetik II, § 481, 619-20; Ruge 101-02). In The Baths of Lucca (Die Bäder von Lucca) from 1830, Heine had only just claimed the term for himself and his own idea of poetry. In difficult times like these, a poet's mind must necessarily be torn apart; whoever professed not to feel this rupture and went on trying to emulate the ancient artists either disgracefully deluded himself or gave away his insensitive and indifferent egotism (DHA 7.1, 95; Preisendanz, Dichtertum 11-20; Betz 11-27). Consequently, Heine's own works were severely censured by German idealist art critics on account of their preoccupation with political and social matters as well as their all-pervasive self-referentiality. To Hegelian aestheticians 
like Karl Rosenkranz, Friedrich Theodor Vischer and Arnold Ruge, he was the paragon of the frivolous artist who openly confessed to his disbelief in the ideal and, instead, focussed on imperfect reality without ever attempting to reconcile the discrepancies (Vischer, Erhabene 214). Especially Heine's idea of humour diverged fundamentally from the Hegelians' demand that the comic be totally harmless and conciliatory (Vischer, Erhabene 174-76). Heine, in contrast, believed that humorous art should always rest on the serious grounds of reality. Now that religion was no longer able to curb the lusts of earthly rulers, it was vital to arm oneself with an offensive wittiness ("Angriffswitz") in order to retaliate for their despotism: "nothing will protect you from the wantonness of wealth and power - but death and satire" (DHA 10, 241).

Heine's defence of Decamps against the reproach of caricature is even more puzzling considering the fact that the painter did indeed work as a graphic satirist and caricaturist (figure 2). He belonged to the regular contributors of the French satirical magazine La Caricature, which was founded by Charles Philipon in 1830 and employed draughtsmen like Honoré Daumier, Grandville and Paul Gavarni. As a decidedly political journal, La Caricature incessantly addressed the contradictions between the ideals of the 1830 July Revolution and the actual political and social state of affairs. Its satirical attacks mainly focused on King Louis Philippe and his ministers, who were being accused of opportunism and fraud. The graphic artists ridiculed their butts by distorting their facial and physical features at their own subjective discretion. Moreover, the persons thus caricatured were often accompanied by surreal symbols and allegories or transferred into parabolic situations which existed but in the artist's mind. ${ }^{82}$ One might therefore have expected that Heine would acknowledge caricature as a genuinely modern form of expression and the artists employing it as kindred spirits. Instead, he repeatedly pronounced his dislike for this kind of mischief ("Unfug"), which he claimed to find annoying and repulsive ("lästig und widrig"). The fact that most of these engravings were designed to ridicule the King, professedly struck him as especially outrageous. Instead of amusing him, they rather made him feel a certain liking and sympathy ("eine gewisse Sympathie") for Louis Philippe (DHA $12.1,124 ; 207-8)$.

Heine's refusal of caricature thus appears as odd as its justification. After all, the political poet Heine was himself no less notorious for his liberal opinions than for his caustic irony and his merciless

82 In this article, the term 'caricature' does not refer to pictorial or graphic satire as a genre, but to the artistic means of representing a single figure in an exaggerated manner, which can (but does not necessarily have to) be employed in a satiric drawing (Fasshauer, Wahre Charaktere 19-20). For the varying meanings of the term in different languages and times see Unverfehrt (Karikatur 345-54). 


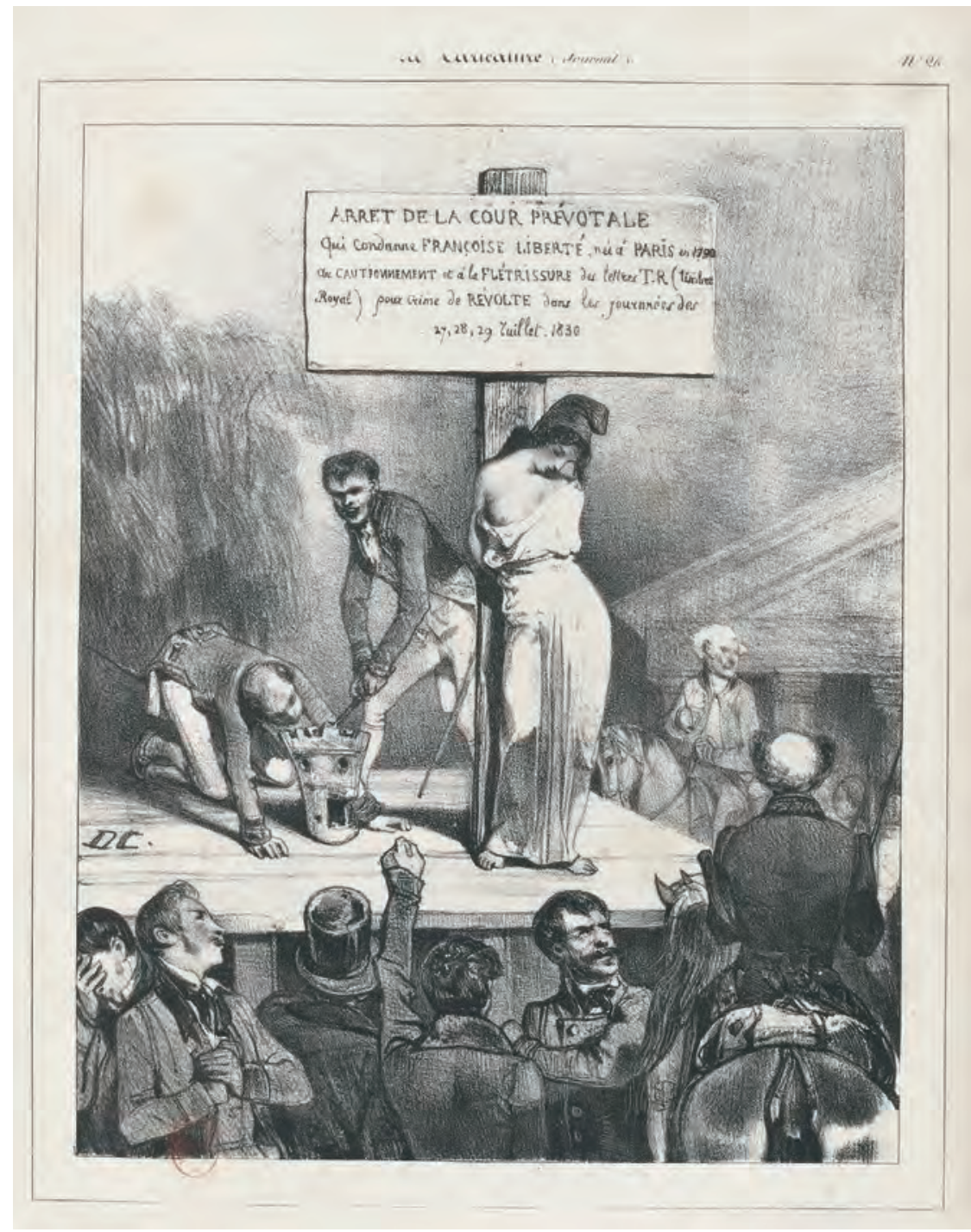

Fig. 2. Alexandre Gabriel Decamps (1803-1860), Arrêt de la cour prévotale qui condamne Françoise Liberté, née à Paris en 1790 du Cautionnement et á la Flétrissure des lettres T.R. (timbre Royal) pour crime de Révolte dans les journées des 27, 28, 29 juillet. 1830. (Arrest by the special court which sentences Françoise Liberté, born in Paris in the year 1790 , to payment of a bail and to branding with the letters T.R. due to the crime of revolt during the 27 , 28 und 29 July 1830), 1831. Lithography, $237 \mathrm{x}$ $189 \mathrm{~mm}$. La Caricature 13 (27 January 1831), Pl. 26. https://gallica. bnf.fr/ark:/12148/ bpt6k1048856w/f5.item 
satire which neither spared politicians nor monarchs. While he otherwise championed the cause of subjectivity in poetry as well as in painting, he does not seem to have considered French graphic satires proper works of art. Instead, he treated them like anonymous flysheets. Apart from Philipon, he never mentioned any of the artists by name.

Earlier research has made several attempts to explain these contradictions. Werner Hofmann, Susanne Zantop and Peter Uwe Hohendahl held that Heine had remained faithful to idealist aesthetics concerning the visual arts in spite of his progressive idea of poetry (Hofmann 75-86; Zantop 5; Hohendahl 28). Hofmann, moreover, attributed Heine's dislike of the pear satires to a genuine admiration he had cherished for Louis Philippe (Hofmann 75). Hellmut Thomke again explained it by Heine's enthusiasm for the Saint-Simonist doctrine in the early 1830 s which had led him to consider the distortion of human features incompatible with the sanctification of mankind on earth (Thomke 126-28), and Alexandra Böhm most recently derived it from an indebtedness Heine had felt to the legacy of Enlightenment and its vehement disapproval of personal satire (Böhm 261-63).

The prospect of a much more satisfactory explanation seems to present itself in a more critical approach to Heine's remarks on graphic satire and their examination for possible intermedial relations. With respect to the French Affairs (Französische Zustände), Bodo Morawe has already identified Heine's ostentatious monarchism as a simulation which allowed him to conceal his actual democratic convictions and nevertheless articulate them from a seemingly negative point of view (Morawe, Französische Zustände 12-39). Curiously enough, the author has not applied this concept to Heine's rejection of La Caricature's graphic satire, which, I argue, is essentially owing to his ironic playacting. Morawe thus misses the manifold analogies between the prints and Heine's reports from the early 1830 s both on a content-related and a methodical level. In his article on the intermedial intertwining of graphic satire and journalism under the July Monarchy, he only points out some thematic analogies between the caricatures and Heine's writing, which he believes to have been prompted by current political catchwords (Morawe, "Daumiers Sujets" 71-72). Neither do Siegbert S. Prawer, Terence J. Reed and Jacques Voisine spot more specific references than a general reminiscence of French caricature in Heine's writing which had received an "atmospheric influence" from the satiric drawings (Reed 166; Prawer 4; Voisine 220). Similarly, Michel Espagne finds only associative parallels between the texts and images and underrates the extent of their agreement (Espagne 159-66). ${ }^{83}$

83 Michel Espagne does, however, show up Heine's reception of Daumier's Robert Macaire-satires and Grandville’s animal prints in his political writings of the 1840s. See also Thomke ("Heine und Grandville"). 


\section{'Thought Smuggling' by Censure: Heine as a Critic of French Caricatural Satires}

Louis Philippe, Duke of Orléans, had ascended to the French throne as a constitutional monarch after the July Revolution of 1830. The fact that the Republicans consented to his enthronement was chiefly owed to the fact that he was supported and publicly declared the "best republic" by the popular hero Marie-Joseph Motier, Marquis de Lafayette, who had already fought in the American Revolutionary war against the British crown. Lafayette had developed a new constitution including several demands from the republican camp, among them an unrestricted freedom of the press. ${ }^{84}$ Shortly after its coming into force, however, this assurance was restricted again by the imposition of compulsory levies for political journals. Moreover, a newly enacted law forbade that the King's person be disrespected or ridiculed in any way (Döring 27-28; Bosch-Abele 1, 41). The republican journalists thus felt betrayed by the Citizen King's opportunism and abuse of their confidence. After all, their protest against Charles X's restrictive July Ordinances had essentially contributed to the outbreak of the revolution which had brought Louis Philippe to power. In spite of the new decree, therefore, the King continued to be the favorite butt of their verbal and graphic satire (Unverfehrt, Karikatur 10; Döring 28, Bosch-Abele 1, 24-25; Rütten 84-85).

Philipon, the editor-in-chief of La Caricature, was charged of lese-majesty several times. One of his trials was set off by a print in which he had depicted Louis-Philippe as a plasterer whitewashing a wall and covering up the bullet-holes and paroles of July (figure 3). In his hearing on 14 November 1831, Philipon defended himself as follows: in drawing the King's features, he had not intended to insult him in person but only to represent the state power in general, the King merely being its first representative. After all, one could find resemblances to the Sovereign in any object if one only tried. In order to prove his thesis, he drew four sketches showing the gradual metamorphosis of the King's face into a pear (figure 4). Although the artist was still convicted for his plasterer-satire, his strategy of defense caused such a sensation that the pear could soon be seen anywhere: not only did it appear in countless graphic satires, but also as a graffito in the streets of Paris. More importantly, Philipon had found a way to successfully avoid press censorship: an investigator who discovered similarities between the monarch and a pear would only compromise himself, as the analogy would have to be ascribed to his own and obviously willful subjective interpretation (Bosch-Abele 1, 188; Rose 115-17).

84 See the Charte constitutionnelle $d u 14$ aout 1830, available at http://www.conseil-constitutionnel.fr/conseilconstitutionnel/francais/la-constitution/les-constitutions-de-la-france/charte-constitutionnelle-du-14-aout1830.5104.html (accessed 21 December 2017). 
Fig. 3. Charles Philipon (1800-1861), Untitled, 1831. Lithography, 285 x $235 \mathrm{~mm}$. $L a$ Caricature 35 (30 June 1831), Pl. 70. http:// gallica.bnf.fr/ark:/12148/ bpt6k1048560r/f7.item

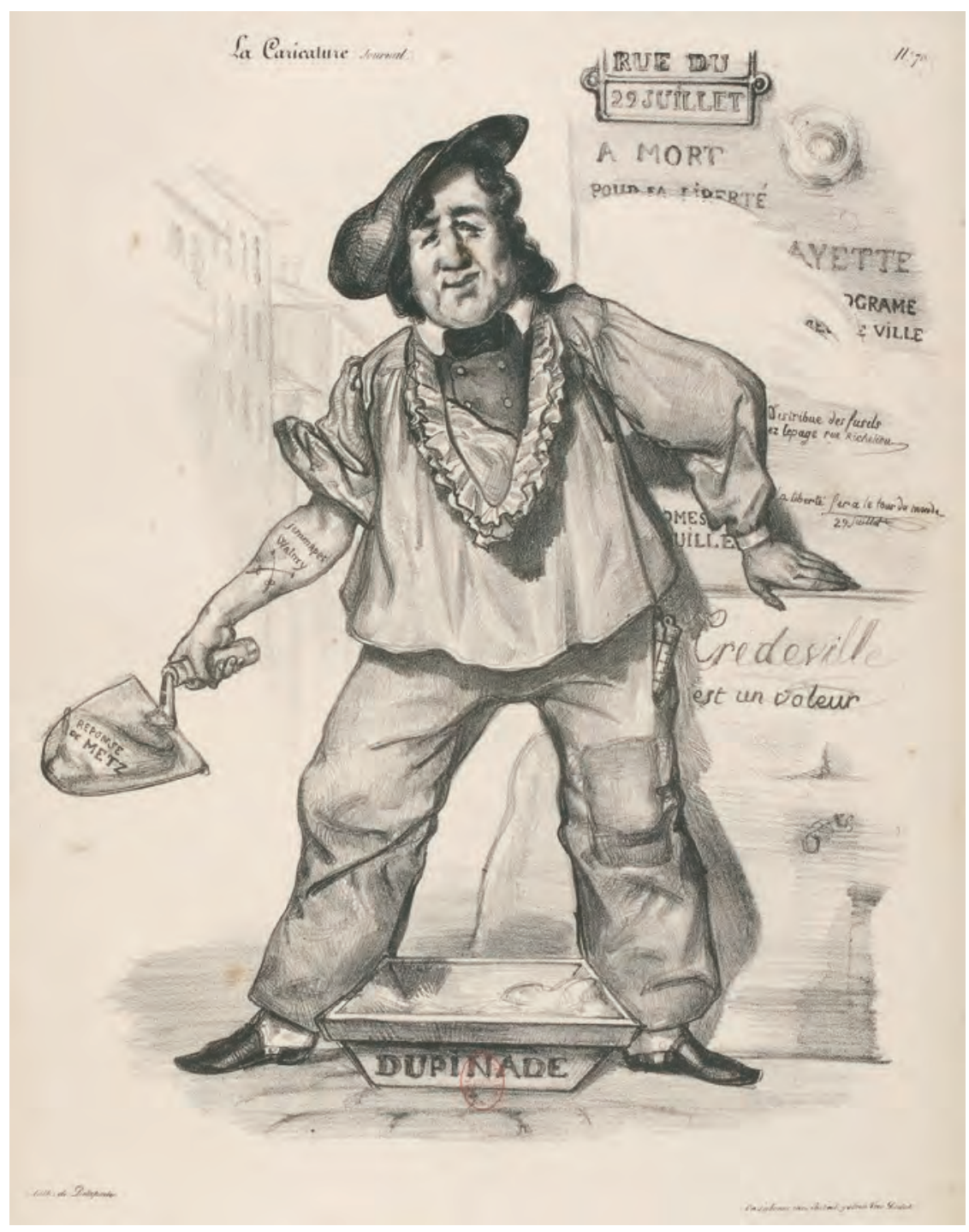




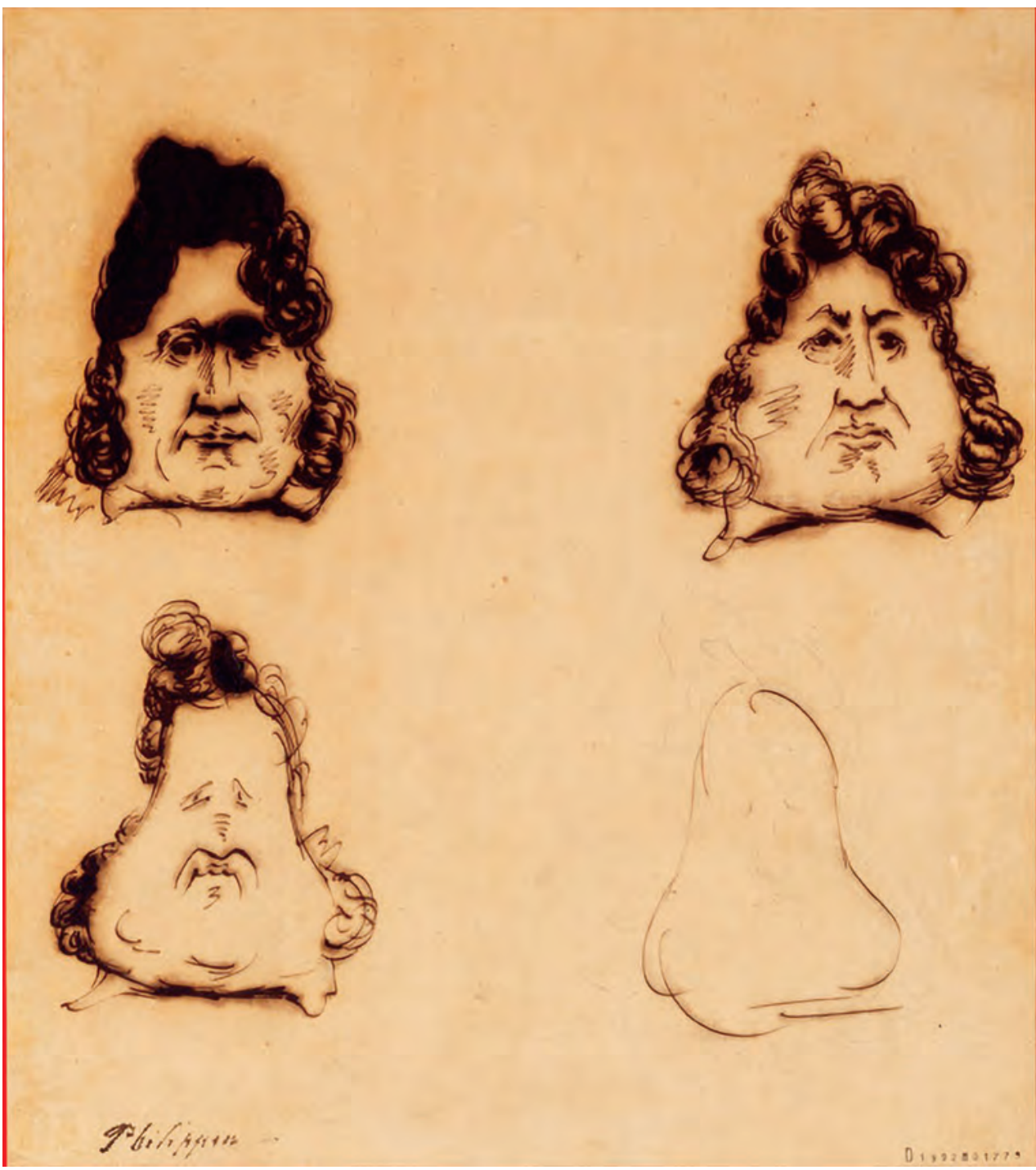

Fig. 4. Charles Philipon (1800-1861), Untitled (The Pear Sketches) 1831. Ink on paper, 24,7 x $21,7 \mathrm{~mm}$. Bibliothèque nationale de France, Estampes et Photographie, Rés. B-16-Boîte. http:// expositions.bnf.fr/ daumier/grand/017_2.htm 
Heine had observed this trial with interest, as he admits in the first article of his Französische Zustände (French Affairs) which appeared in Cotta's Allgemeine Zeitung from January to July 1832. It was certainly most reprehensible that the King's face had been chosen for a subject of countless caricatures which were sold all over the city. In trying to restrain these lampoons, however, the authorities had only made things worse: the trial against Philipon, for instance, had resulted in an even greater and more far-reaching ridicule of the monarch (DHA 12.1, 81). Then again, the discontent and anger of the republicans were quite understandable, as the Citizen King obviously behaved more and more like an absolute monarch:

Ja, täglich geschehen offenbare Rückschritte, und wie man die Pflastersteine, die man in den Juliustagen als Waffe gebrauchte, und die an einigen Orten noch seitdem aufgehäuft lagen, jetzt wieder ruhig einsetzt, damit keine äußere Spur der Revoluzion übrig bleibe: so wird auch jetzt das Volk wieder an seine vorige Stelle, wie Pflastersteine, in die Erde zurückgestampft, und, nach wie vor, mit Füßen getreten (DHA 12.1, 82; Yes, there are certainly every day most evident retrogressions; and just as they are now quietly replacing the paving-stones which were used in the days of July as weapons, so that no external trace of the Revolution may be visible, so the people are again being stamped into their previous place like paving-stones, and trodden as before under foot).$^{85}$

Heine's disapprobation of the pear caricatures at the beginning of this passage functions only as a preamble to his own critical statements on the King's fraudulent ungratefulness. Without a single mention of Philipon's plasterer-print, he picks up not only its topic but also the image of the construction worker covering the traces of the street-fights. His unreserved approval of this particular, but unmentioned, satire thus makes his wholesale censure of republican caricature appear more than doubtful, and his professed dislike is unmasked as a tongue-in-cheek expression of his own malicious glee.

The first article of the French Affairs did not only appear in the Allgemeine Zeitung, but also in the French republican newspaper Tribune des Républicains. While the editor was subsequently put on trial for lese-majesty, Heine himself evaded prosecution only because the article had been printed anonymously (Morawe, Französische Zustände 25-26). The sensation he had caused induced him to proceed more carefully in the future: Even though he stopped publishing his articles in French papers for the time being, he would still have to face German censorship, severely penalizing all kinds

85 My translations from Heine's Französische Maler and Französische Zustände are loosely based on those of Charles Godfrey Leland (Leland). 


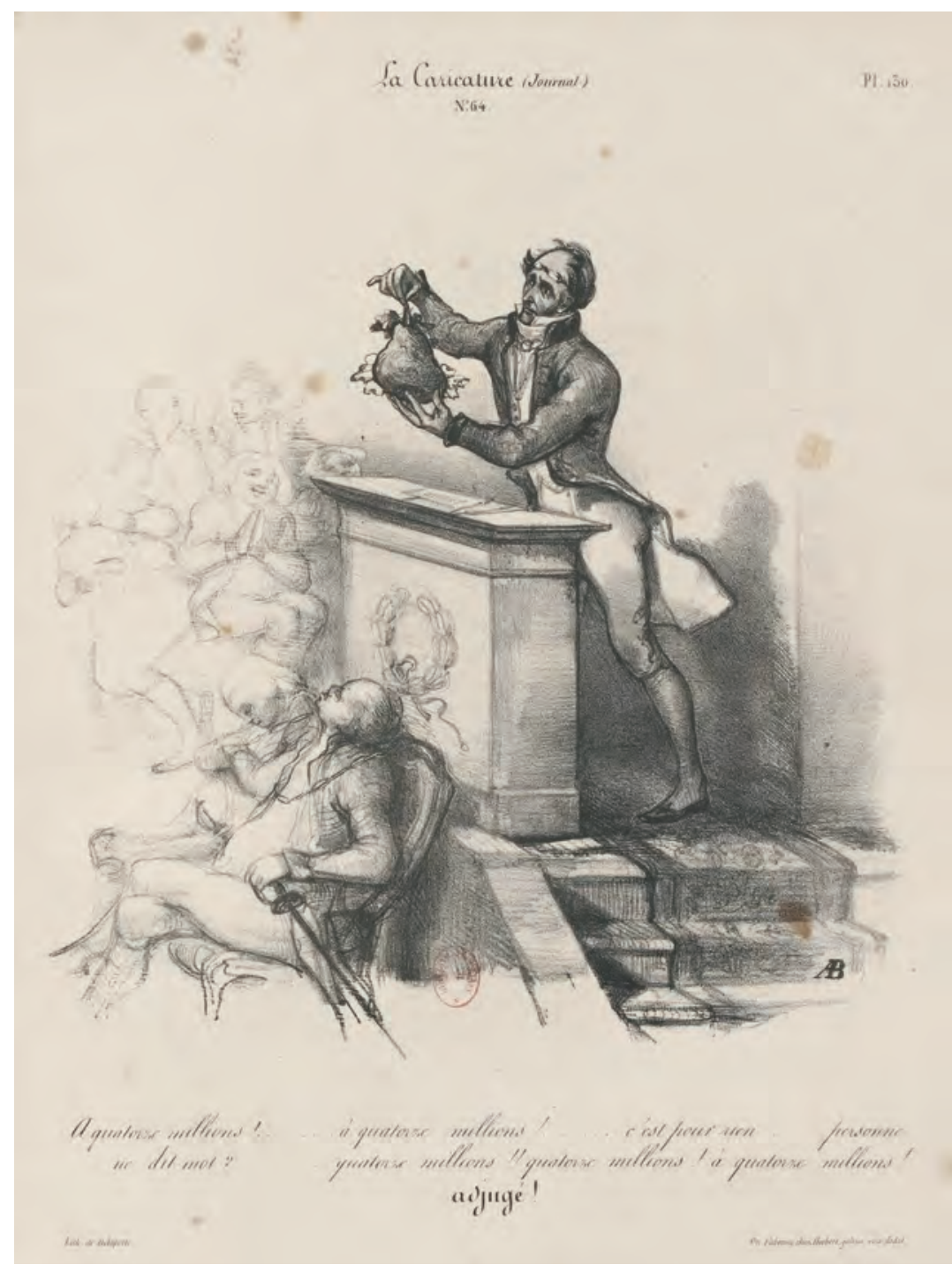

Fig. 5. Auguste Bouquet (1810-1846), À quatorze millions! ... à quatorze millions! ... c'est pour rien ... personne ne dit mot? ... quatorze millions!! quatorze millions! à quatorze millions! / Adjugé! (Fourteen millions ... fourteen millions, that's a giveaway ... does anyone bid more? ... Fourteen millions!! Fourteen millions! Gone!), 1832. Lithography, 207 x 196 mm. La Caricature 64 (19 January 1832), Pl. 130. http:// gallica.bnf.fr/ark:/12148/ bpt6k1048906b/f7.item 
of liberal thought. In his second article, he therefore rushes to express his monarchist conviction: a royalist by inborn inclination, he had become even more so in France from conviction; also, he was convinced that the French were not able to tolerate a republic (DHA 12.1, 88). In article five from 25 March 1832, he finally comes back to the pear caricatures which were still to be seen everywhere. Apparently at random, he picks a few examples and describes them briefly with feigned disgust (DHA 12.1, 123-24). However superficial these short accounts may seem at first glance, they turn out to be accurate descriptions of some of the most significant graphic satires which had appeared in $L a$ Caricature between January and March 1832. In the first of these prints (figure 5), Auguste Bouquet has depicted the French Prime Minister Périer as an auctioneer selling off the pear he holds in his hand for fourteen million francs, and thus turned against the governmental allowance for the King which the republicans regarded as an absolutist relic. In the second picture, Daumier had the outsmarted Lafayette lie uncomfortably on a sofa and squirm in a nightmare with a huge pear sitting on his chest and the original constitution clutched in his hand (figure 6). In the third one entitled The juste-milieu sullies itself, Joseph-Charles Traviès referred to Louis Philippe's policy of non-intervention with regard to the liberation movements in Spain, Italy and Poland. Although all of these uprisings had been inspired by the July Revolution, the French government denied them military support and left the revolutions to be suppressed and their leaders to be executed. The artist let Périer and the Foreign Secretary Sebastiani appear as clowns dressed in the French Tricolor, wading through a muddy puddle and carrying a large spattered pear on a staff over their shoulders (figure 7). ${ }^{86}$

All of these topics had already been treated in the second article from 19 January. With the air of a neutral observer, Heine had critically reviewed the daily press and quoted statements from different political camps concerning the latest political developments. Considering the increasing public criticism of Louis Philippe, the monarchist Journal des Débats had exhorted the republican papers to have at least pity on the King. In reply, the Tribune des Républicains had brought back to mind the lack of compassion Louis Philippe had shown for the other European revolutionaries: “'Pity on Louis Philippe!' replied the Tribune. 'This man asks for fifteen millions and our pity! Did he have pity on Italy, on Poland?"' Without commenting on the diverging opinions he has just quoted, Heine adds:

Ich sah diese Tage die unmündige Waise des Menotti, der in Modena gehenkt worden. Auch sah ich unlängst Senora Luisa de Torrijos, eine arme todblasse Dame, die schnell wieder nach Paris zurückgekehrt ist, als sie an der spanischen Grenze die Nachricht von der Hinrichtung

86 See the commentary on this print in La Caricature 71:8 (March 1832): 566-567http://gallica.bnf. fr/ark:/12148/cb344523348/date (accessed 21 December 2017). 


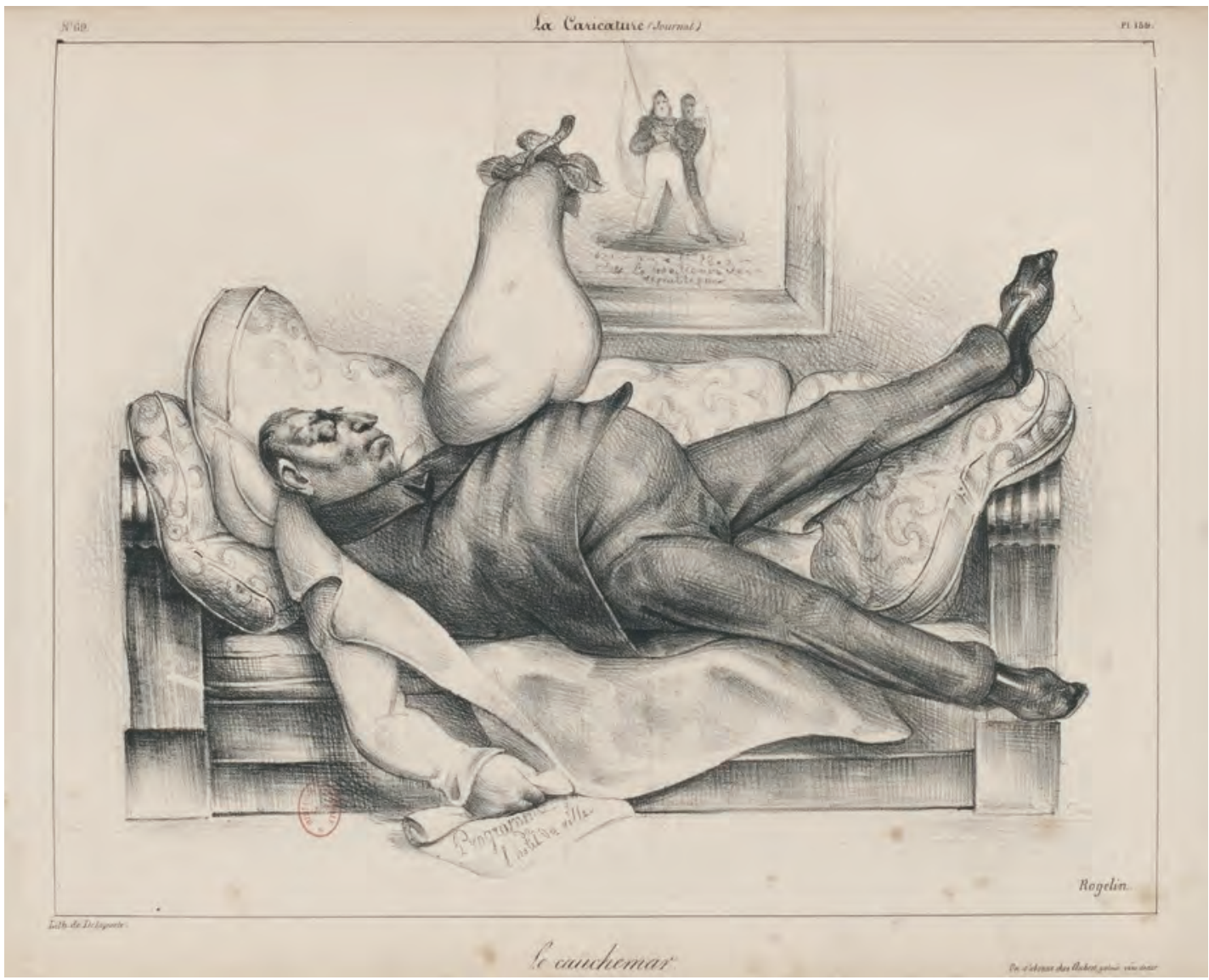

Fig. 6. Honoré Daumier (1808-1879), Le Cauchemar (The Nightmare), Lithography, 232 x 293 mm. La Caricature 69 (23 February 1832), Pl. 139. http://gallica.bnf.fr/ark:/12148/bpt6k1048916q/f5.item 
Fig. 7. Joseph-Charles Traviès de Villers (1804-1859), Le Juste milieu se crotte (The Juste-Milieu Sullies Itself), 1832. Lithography, 176 × $219 \mathrm{~mm} . \mathrm{La}$ Caricature 71 (8 March 1832), Pl. 144. http:// gallica.bnf.fr/ark:/12148/ bpt6k1048920m/f7.item

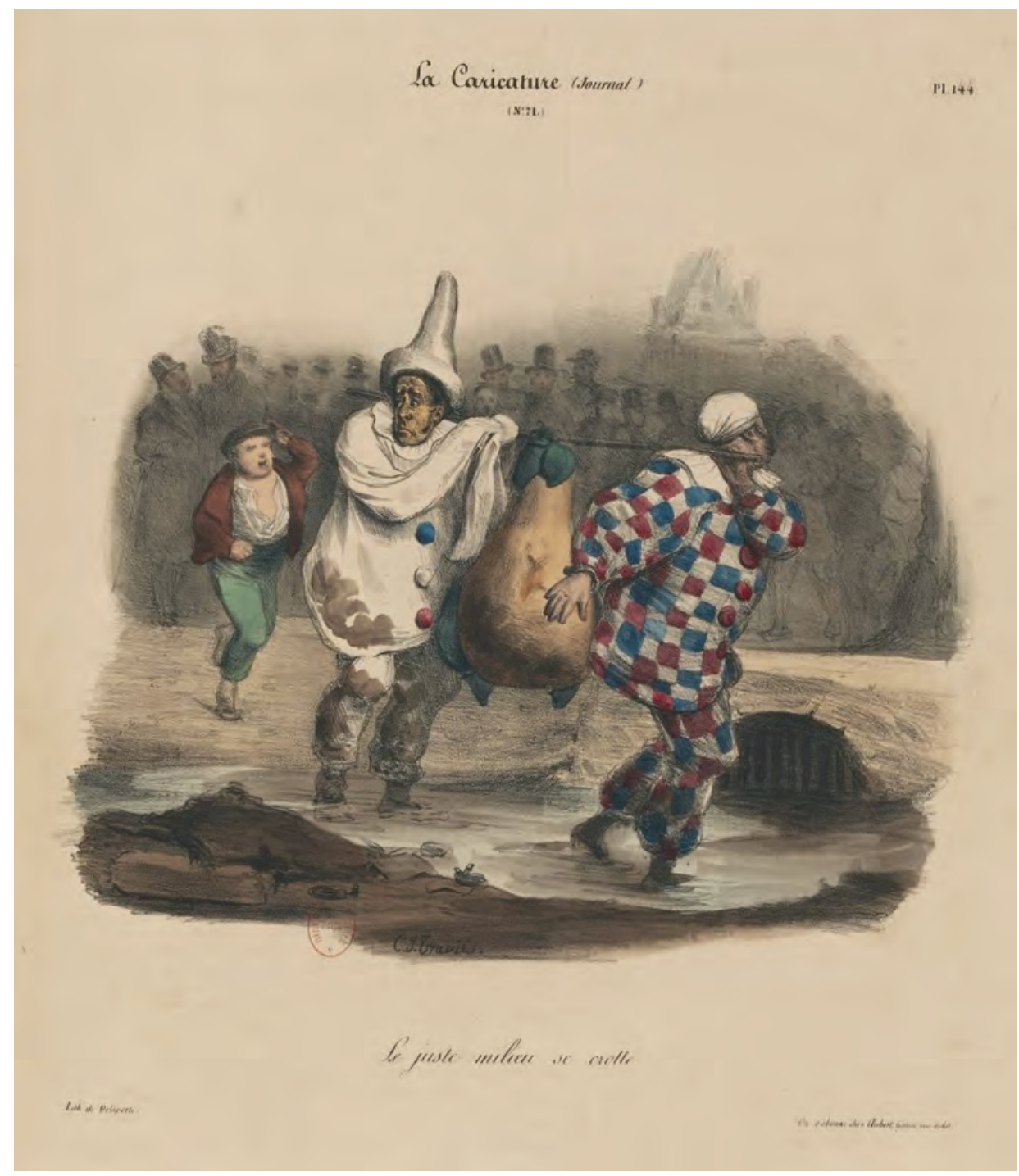


ihres Gatten und seiner zweyundfünfzig Unglücksgefährten erfuhr. Ach, ich habe wirklich Mitleid mit Ludwig Philipp! (DHA 12.1, 86; I saw the other day the under-age orphan of Menotti, who was hung in Modena. I also saw recently Senora Luisa de Torrijos, a poor deathly-pale lady, who quickly returned to Paris when she learned on the Spanish frontier the news of the execution of her husband and of his fifty-two companions in misfortune. Oh, I really pity Louis Philippe!)

Heine's utterance of sympathy for the King in this context hardly goes back to a feeling of true compassion or benevolence, but solely to a scornful condescension because of the monarch's inglorious behavior. Although he does not say so on a verbal level and confines himself to an indicating gesture instead, Heine's true sympathies are unmistakably with the surviving relatives of the revolutionists. Moreover, his exclamation of pity has clear overtones of warning, as Louis Philippe's betrayal of the revolutionary ideals might eventually lead to new riots and perhaps even to the overthrow of his government.

The ambiguous ring of this remark is emphasized by Heine's following mention of openly critical articles in radically republican papers. The satirical magazine Le Figaro, for instance, indulged in cruel ("sanglant") jokes on Lafayette's declaring Louis Philippe "the best republic," which had now turned out to be a near-absolute monarchy and was going to cost the French people fourteen million francs annually (DHA 12.1, 87). Again, Heine's seemingly reluctant quotations almost imperceptibly merge with his own statements, making it nearly impossible to tell whether he is still reporting the opinions of the republican press or stating his private views:

Die Parthey der Republikaner will dem Lafayette seinen Mißgriff in Betreff des empfohlenen Königs nimmermehr verzeihen. Sie wirft ihm vor, daß er den Ludwig Philipp lange genug gekannt habe, um voraus wissen zu können, was von ihm zu erwarten sey. Lafayette ist jetzt krank, kummerkrank. Ach! das größte Herz beider Welten, wie schmerzlich muß es jene königliche Täuschung empfinden! Vergebens, in der ersten Zeit, mahnte Lafayette beständig an das Programme de l'Hôtel de Ville, an die republikanischen Instituzionen, womit das Königtum umgeben werden sollte, und an ähnliche Versprechungen. (DHA 12.1, 87; The Republican party will never forgive Lafayette his mistake concerning the recommended king. They reproach him with having known Louis Philippe long enough to be aware beforehand what was to be expected of him. Lafayette is now sick for grief. Oh! The greatest heart of two worlds, how bitterly it must feel that royal deceit. It was all in vain that he in the beginning continually insisted on the Programme de l'hotel de ville, on the republican institutions with which the monarchy should be surrounded, and on similar promises.) 
Fig. 8. Anonymous, As-tu déjeuné, Jacot? - Valmy! - as tu déjeuné? - Jemmapes! tu dis toujours la même chose. Valmy! - Jemmapes! - Valmy! - Jemmapes! (Have you had lunch, Jacot? - Valmy ! - Have you had lunch? - Jemmapes! You always say the same thing. - Valmy! - Jemmapes! - Valmy! - Jemmapes!). Lithography, 202 x $138 \mathrm{~mm}$. La Caricature 43 (25 August 1831), Pl. 86. http:/gallica.bnf.fr/ark:/12148/ bpt6k1048576m/f5.item

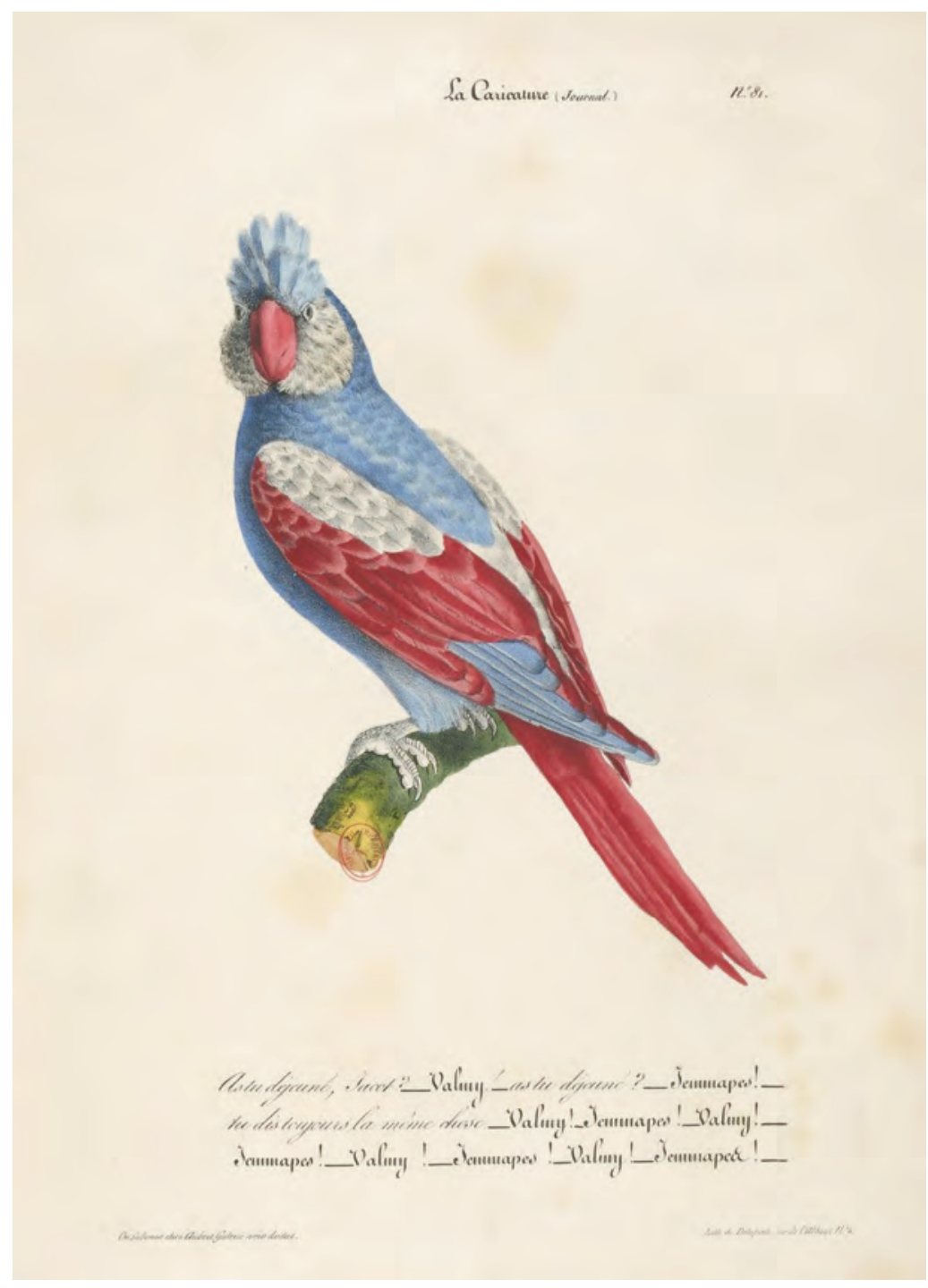


A careful re-reading of the second article thus casts a wholly different light on Heine's descriptions of the satirical prints in article five: it becomes quite obvious that they were by no means picked at random, but in fact chosen very carefully in order to function both as a corroboration and an illustration of the author's own political remarks. In discussing the foreign revolutions and Lafayette's deception, Heine adopts the same disapproving air as in describing the prints, and the debates on the royal alimentation are only touched in passing when the seemingly unbiased foreign correspondent quotes from the daily press. Under the same semblance of impartiality Heine then states: "Ich will wahrlich den Unfug dieser Fratzenbilder nicht vertreten, am allerwenigsten, wenn sie die Person des Fürsten selbst betreffen. Ihre unaufhörliche Menge ist aber eine Volksstimme und bedeutet etwas" (DHA 12.1, 124; I really do not want to defend the mischief of these caricatures, least of all when they concern the person of the Prince. Their incessant multitude, however, is a popular voice and means something). Such prints could be thoroughly pardonable and even salutary as long as they did not offend the King's person but only censured his deception of the people. As an example, Heine mentions the picture of a tri-colored parrot appearing to be a neutral ornithological illustration at first glance (figure 8). According to the caption, however, the bird permanently repeats the words "Valmy" and "Jemmapes", naming two victorious battles of the year 1792 in which the revolutionary French republic had defeated Austria and Prussia. Louis Philippe, who had taken part in these battles, now never missed an opportunity to point out his patriotism and liberal-mindedness. Since the parrot appeared, however, the King had stopped hinting at them as frequently as before:

Er fühlt wohl, in diesen Worten lag immer ein Versprechen, und wer sie im Munde führte, durfte keine Quasilegitimität nachsuchen, durfte keine aristokratischen Instituzionen beybehalten, [...] durfte nicht die Freyheit der übrigen Welt ihren Henkern preisgeben. Ludwig Philipp mußte vielmehr auf das Vertrauen des Volkes den Thron stützen, den er dem Vertrauen des Volkes verdankte. Er mußte ihn mit republikanischen Instituzionen umgeben wie er gelobt, nach dem Zeugniß des unbescholtensten Bürgers beider Welten (DHA 12.1, 124; He probably feels that there was a promise in these words, and he who had them ever in his mouth could not seek for quasi-legitimacy, could not maintain aristocratic institutions, could not leave the liberty of the rest of the world to its hangmen. Instead, Louis Philippe should base upon the confidence of the people the throne, which the confidence of the people bestowed on him. He must surround it with republican institutions, as he has promised to do, according to the testimony of the most blameless citizen of the two worlds).

Although Heine's comment on the print goes beyond its immediate message, it does not "shift" its meaning by changing or politicizing it, as Espagne proposes (Espagne 160-61). The parrot 
print is already essentially political in itself, aiming at the King's broken promises and disappointed hopes no less than Heine's interpretation. Rather, the poet comprehends the King's parroting of his past heroism as an overall expression of the disappointed hopes the republicans had set in him. The latest significant instances of Louis Philippe's deceitful behavior, however, have been treated in the graphic satires Heine has mentioned before. After having described them only phenomenally in the first place, he is now turning to their contents at last: the King's insisting on a civil list, his neglect of the foreign revolutions and his abuse of Lafayette's confidence. Instead of shifting the meaning of the parrot print, then, Heine rather detaches the messages of the graphic satires from the form they are presented in. This strategy not only enables him to distance himself from the pear caricatures and to affirm every single aspect of their criticism at the same time, but also nullifies his alleged indignation at the pear caricatures which he has in fact never believed to intend merely a personal invective against the King. Similarly, his qualitative distinction between the pear satires and the parrot is overturned: by this time, the pear had long ceased to caricature Louis Philippe exclusively but turned into an impersonal and arbitrary symbol denoting the King along with his parliament and the whole concept of the July Monarchy. The parrot print, on the other hand, is not only taking up one of Louis Philippe's individual characteristics but also compares him directly to an irrationally screaming animal and therefore results in a far greater personal insult. Heine's explicit approval of the parrot is thus unmasking his censure of the pear caricatures as a mere charade.

Hence, the assumption suggests itself that Heine's professed depreciation of French graphic satire caricaturing the monarch was only another instance of what he would later refer to as "thought smuggling” (“Gedankenschmuggel”):

Ich mußte das Schiff meines Gedankens oft mit Flaggen bewimpeln, deren Emblème nicht eben der rechte Ausdruck meiner Gesinnung waren. Aber den publizistischen Freybeuter kümmerte es wenig von welcher Farbe der Lappen war, der am Mastbaum seines Fahrzeugs hing und womit die Winde ihr luftiges Spiel trieben: ich dachte nur an die gute Ladung die ich an Bord hatte und in den Hafen der öffentlichen Meinung hineinschmuckeln wollte (DHA 13.1, 293; I was often obliged to hoist a flag over my boat of thought, which very inaccurately expressed my true political or social views. But the journalistic smuggler does not concern himself much as to the colour of the bit of bunting which he puts on the mast of his vessel, [...] and I thought only of the good cargo which I had on board, and which I wished to land in the harbour of public opinion. 
In order to inform his German readers comprehensively of the political and social developments in France without taking the risk of having his texts mutilated or suppressed by press censorship, it had often been necessary to cover up his true opinions and convey them in disguise. A very effective way of doing so, he found, was masking his subjective thoughts as accounts of objective facts. Sometimes he would therefore have fictitious persons utter his personal opinions, or quote from books and press statements upon which he pretended to look with indifference or even with disapproval (DHA 13.1, 293; Höhn; Hömberg 32-33; Ziegler 144-47; Radlik 460-89). Just like the graphic artists employing the pear symbol, Heine couched his criticism of Louis Philippe in unsuspicious forms and made the detection of offensive statements appear as the censors' subjective interpretation.

\section{The Pear, the Fir and the "Sponge-bellied Petty Citizen": Heine's Literary Caricatures of the Citizen King}

The suspicion that Heine's disparagement of the pear caricatures was nothing but a defensive lie becomes even more evident by the fact that Heine himself had already caricatured Louis Philippe's head by comparison to a herbal object before the pear symbol was even invented. In his first two articles on the Salon which appeared in the Morgenblatt on 27 and 28 October 1831, he had discussed a painting by Ary Scheffer showing Louis Philippe in his function as Lieutenant General on horseback (figure 9). Although he claimed to have found the picture very like altogether, the head to his mind was rather over-idealized and not tapering so much to a point as it should; for whenever he looked at the original, this characteristic feature reminded him of the folk song: "Es steht eine Tann im tiefen Thal,/ Ist unten breit und oben schmal" (DHA 12.1, 15; A fir-tree in the vale does grow, "tis thin above and broad below"). There is indeed a German folksong song containing these lines; it does, however, not mention a fir but a lime tree exhibiting a far less angular silhouette (Busch 157). By tacitly changing the lime into a fir, Heine for one thing travesties a pre-existing work of art, just like Daumier had turned Johann Heinrich Füssli's Nightmare into a political satire (figure 10). Moreover, his association of the King's head with a tree outline is as schematizing a simplification as Philipon's fruit comparison (figure $11 \mathrm{~A}$ ). By implicitly exaggerating his tree caricature, he furthermore raises it to an even higher degree corresponding with one of the advanced stages of the King's metamorphosis into a pear (figures $11 \mathrm{~B}$ and $\mathrm{C})$.

Heine, however, not only invented his own strategies of caricature but also adopted the pear symbol and allowed it to develop a life of its own. Having turned into an abstract emblem almost immediately after its creation, the pear symbol outgrew its journalistic context and kept reappearing as 
Fig. 9. Johann Heinrich Füßli (1741-1825), Le Cauchemar (The Nightmare), 1781. Oil on canvas, 760 x $640 \mathrm{~mm}$. Frankfurt am Main, Freies Deutsches Hochstift, Goethemuseum. https://de.wikipedia. org/wiki/Datei:Johann Heinrich_F\%C3\%BCssli_053.jpg

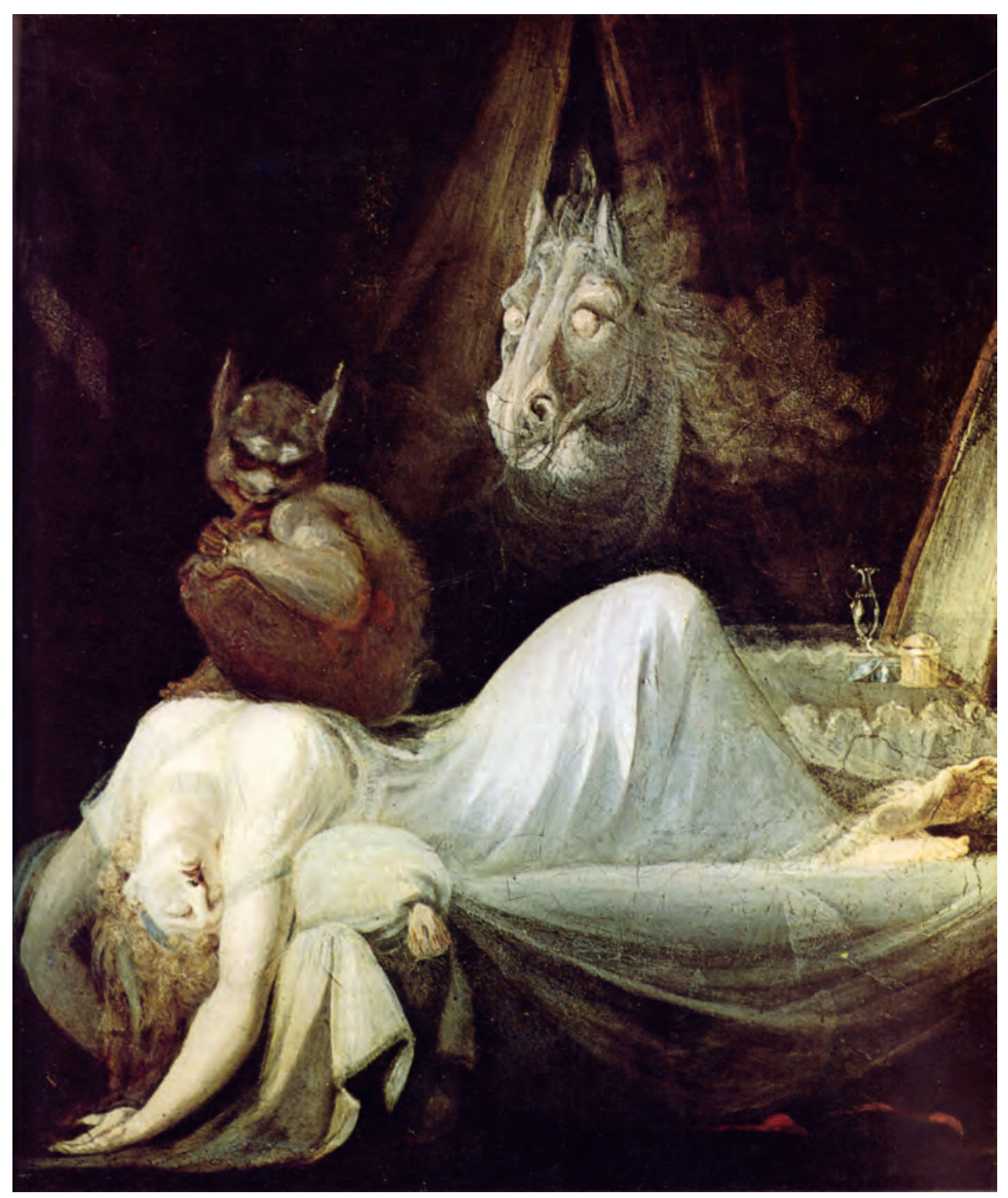




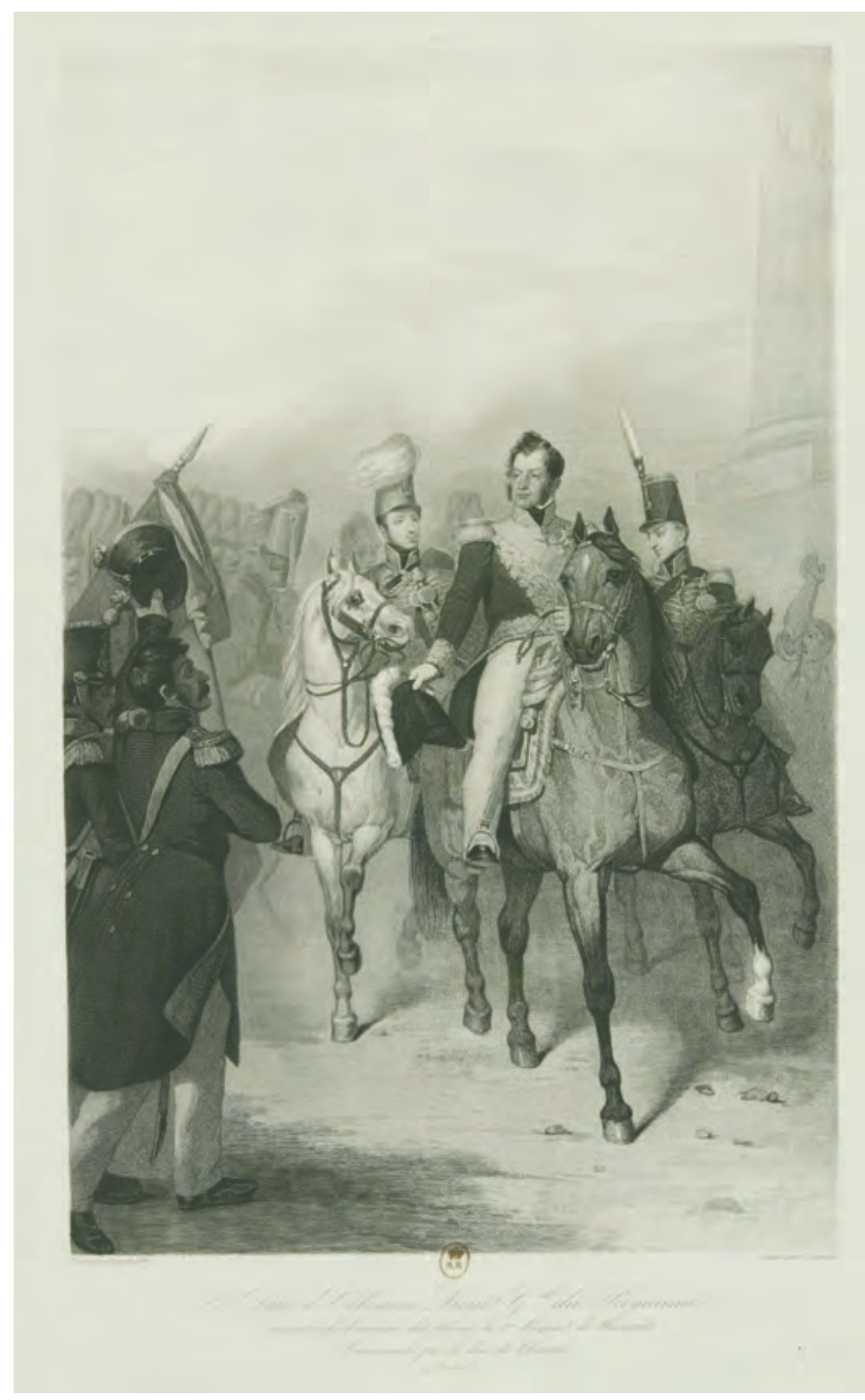

Fig. 10. Zachée Prévost (1797-1861) after Ary Scheffer (1795-1858), Le Duc d'Orléans, Lieutenant Général du Royaume reçoit à la barrière du trône le ler régiment de hussards commandé par le duc de Chartres, 4 août 1830, 1831. Etching, $450 \times 295 \mathrm{~mm}$. (Original painting: Oil on canvas, $1190 \times 905$ mm, Versailles, Châteaux de Versailles et de Trianon). https://gallica.bnf.fr/ark:/12148/ btv1b100210069.r=ary\%20scheffer $\% 20$ duc?rk=21459;2 

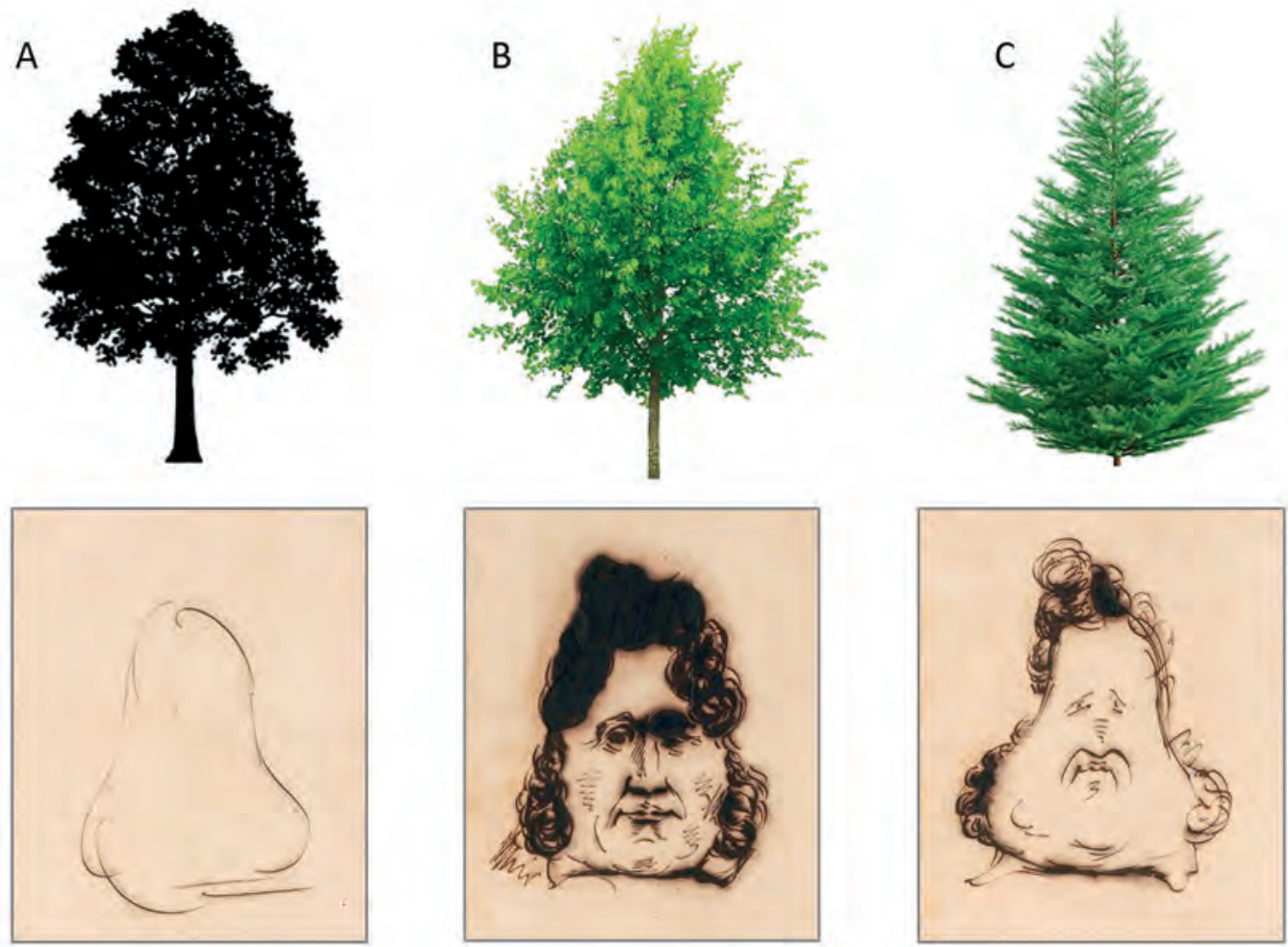

Fig. 11. Tree silhouettes (lime and fir) compared to Philipon's Pear Sketches (figure 4) 
a graffito in the public places of Paris. As before with respect to the graphic satires from La Caricature, he also stated his disapproval of these grotesque drawings which most disrespectfully mocked the monarch in his own capital. Instead of laughing at the King, however, the French should rather laugh at themselves: "er denkt, wer zuletzt lacht, lacht am besten; Ihr werdet die Birne nicht fressen, die Birne frißt Euch" (DHA 12.1, 57; he thinks to himself, he who laughs last laughs best; you will not eat the pear, but the pear will eat you). The Citizen King's progressive transformation into an absolute monarch should by now have taught the doodlers that he was by no means as harmless as they might think, and that they should be prepared for his revenge. What looks like a warning to the French satirists and graffito artists at first glance, reveals itself on closer scrutiny to be a severe condemnation of the King's deceitful hypocrisy. Again, Heine employs the strategy of apparent disapproval and actual affirmation. From this changing perspective, his warning of any more caricatures turns into the opposite. Their growing number to him is only a symptom of the worsening political situation which necessitates not an appeal for a cessation, but in fact an increased continuation of satirical criticism. The King himself no longer appears as a victim of ill-natured slander, but rather as the most dangerous enemy of his own people, and Heine's warning turns out not to be meant as a good-hearted mediation in terms of moral behavior and loyalty to the sovereign but, rather, to refer to the King's vengeance which might be terrible and merciless.

The insincerity of Heine's warning not to publish any more graphic satires on the King is significantly revealed by the fact that he eventually confirms it with a literary caricature of his own:

Er war nicht mehr der gutmüthige, schwammbäuchige Spießbürger, das lächelnde Fleischgesicht; sogar seine Korpulenz gab ihm plötzlich ein würdiges Ansehn, er warf das Haupt so kühn in die Höhe wie es jemals irgend einer seiner Vorfahren gethan, er erhob sich in dickster Majestät, jedes Pfund ein König (DHA 12.1, 58; He was no longer the good-natured, sponge-bellied petty bourgeois and laughing face of flesh; even his corpulence suddenly gave him a dignified appearance, he raised his head as boldly as any of his ancestors had done, he rose in weightiest majesty, every pound a king).

In singling out his corpulence and overstressing it, Heine employs a classic means of physical caricature consisting in the extreme exaggeration of certain corporeal features and the subsequent distortion of the whole figure (Vischer, Ästhetik I, § 149, 361; Rosenkranz 310-12). The same technique was repeatedly used for instance by Daumier, in whose graphic caricatures Louis Philippe's exaggerated corpulence not only served as a means of ridicule but often functioned also as a distinguishing mark of the Citizen King whose face he was not allowed to represent. Both artists, then, employ not only 
similar satiric means but also analogous methods of avoiding censorship: Heine disguises his physical caricature - just like his satiric critique - as a display of respect and adoration, while Daumier uses his mocking hyperbole as an unambiguous identifier of his butt. Again, in both cases the realization that the representation is intended to be a caricature of Louis Philippe is being accomplished by the recipient's subjective interpretation.

Other unsuspicious and yet unequivocal symbols Daumier used to denote the King without actually portraying him were a felt hat with a tricolor cockade, an umbrella, the characteristic pointed quiff and over-luxuriant sideburns (figure 12). In order to win the people's confidence and acquire the crown, Louis Philippe had at first ostensibly demonstrated his bourgeois sentiments by walking the streets of Paris in middle class attire and distributing smiles and handshakes. As they were worn by every second Parisian citizen in those days, the depiction of such fashionable accessories could no more be punished than the use of the pear symbol or the representation of a figure with a stout physique. This means of caricature became more expressive the more the King deviated from this artificial character and revealed his actual self, as it simultaneously ridiculed both the monarch's feigned bourgeois persona and his actual absolutist endeavors. Just like the pear, all of these significant objects found their way into Heine's articles where they broke entirely free from the graphic medium. Starting from a hint at the cartoons representing the King by means of his bourgeois outfit, the felt hat and the umbrella turned into stage properties which, along with his handshakes, belonged to the role Louis Philippe had so convincingly played in order to secure his power. The King himself is bestowed with the dubious compliment of being the world's most skillful and cunning play-actor:

Kein Schauspieler auf dieser Erde hat sein Gesicht so sehr in seiner Gewalt, keiner weiß so meisterhaft seine Rolle durchzuspielen wie unser Bürgerkönig. Er ist vielleicht einer der geschicktesten, geistvollsten und muthigsten Menschen Frankreichs; und doch hat er, als es galt die Krone zu gewinnen, sich ein ganz harmloses, spießbürgerliches, zaghaftes Ansehen zu geben gewußt (DHA 12.1, 57); No actor in the world has his own face so completely at command, no one knows how to play a part through in such masterly manner as our CitizenKing. He is perhaps one of the cleverest, wisest, and bravest men in France, and yet he was perfectly able, when it was necessary to win the crown, to assume a thoroughly harmless, small citizen-like, timid air).

However, when the growing opposition from the republican camp made him realize that his power was not quite so secure after all: 


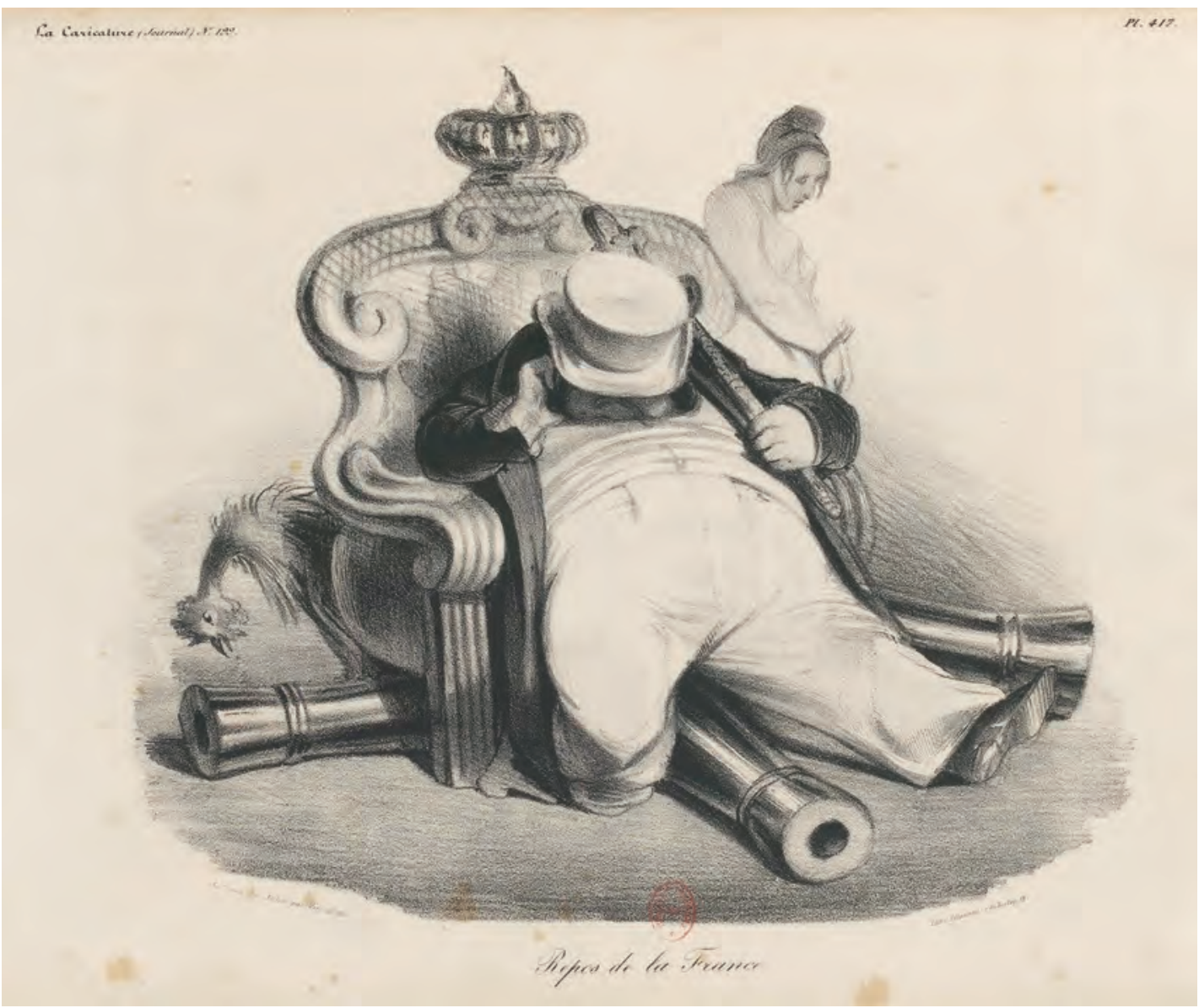

Fig. 12. Honoré Daumier (1808-1879), Repos de la France (The Sleep of France). Lithography, 215 x 262 mm. La Caricature 199 (28 August 1834), P1. 417. https://gallica.bnf.fr/ark:/12148/bpt6k1048734z/f7.item 
wie schnell hatte er wieder den alten Filzhut aufgestülpt und seinen alten Regenschirm zur Hand genommen! Wie bürgerlich, einige Tage nachher, bey der großen Revüe, grüßte er wieder Gevatter Schneider und Schuster, wie gab er wieder rechts und links die herzlichsten Poignées de main, und nicht bloß mit der Hand, sondern auch mit den Augen, mit den lächelnden Lippen, ja sogar mit dem Backenbart! (DHA 12.1, 58; how soon he had popped the old felt hat back on his head and took the old umbrella in his hand! How modestly and cordially, a few days later at the great review, he greeted his old acquaintance the tailor and the cobbler, and right and left gave the most heartfelt handshakes; and not only with his hand, but also with the eyes, with the smiling lips, yes, even with the sideburns!)

Daumier, too, repeatedly depicted Louis Philipp as a masked comedian who outwardly performed the opposite of what he really felt and desired. Apart from serving the artist as yet another way of concealing the King's features, the mask also expressed the very inclination to dissimulation and deceit that Heine attributed to him as well. In a cartoon entitled Principal acteur d'un imbroglio tragico-comique (fig. 13), Louis Philipp is wearing a white silken jacket with a large medal and riding boots in which he is stepping on the charter guaranteeing the prerogatives of the two parliamentary chambers. While leaning on his sword with his left hand, the right one is carrying a scepter wrapped in the monarchist Count Roederer's Adresse d'un constitutionnel aux constitutionnels defending the King's personal prerogative in all governmental matters. The umbrella has only just been dropped, as have the citizen's coat which has been replaced by a princely ermine cloak, the top hat makes room for a large royal crown, and the smiling mask which brings to light an air of unscrupulous fierceness. This cartoon bears a striking resemblance to a passage from the fifth article of Heine's French Affairs:

Was Ludwig Philipp betrifft, so spielt er noch immer seinen Roi-citoyen, und trägt noch immer das dazu gehörige Bürgerkostüm; unter seinem bescheidenen Filzhute trägt er jedoch, wie männiglich weiß, eine ganz unmaßgebliche Krone von gewöhnlichem Zuschnitte, und in seinem Regenschirme verbirgt er das absoluteste Scepter. Nur wenn die liebsten Interessen zur Sprache kommen, oder wenn einer mit dem gehörigen Stichworte die Leidenschaften aufreitzt, dann vergessen die Leute ihre einstudirte Rolle und offenbaren ihre Persönlichkeit. (DHA 12.1, 120; As for Louis Philippe, he always plays his part of roi-citoyen, and wears the citizen dress appropriate to it; but under his modest felt hat, as is generally known, he wears an altogether insignificant crown of the usual form, and in his umbrella he hides the most absolute scepter. It is only when their nearest and dearest interests are discussed, or when someone awakes their passions with the proper catchword, that men forget their studied parts and reveal their character.) 


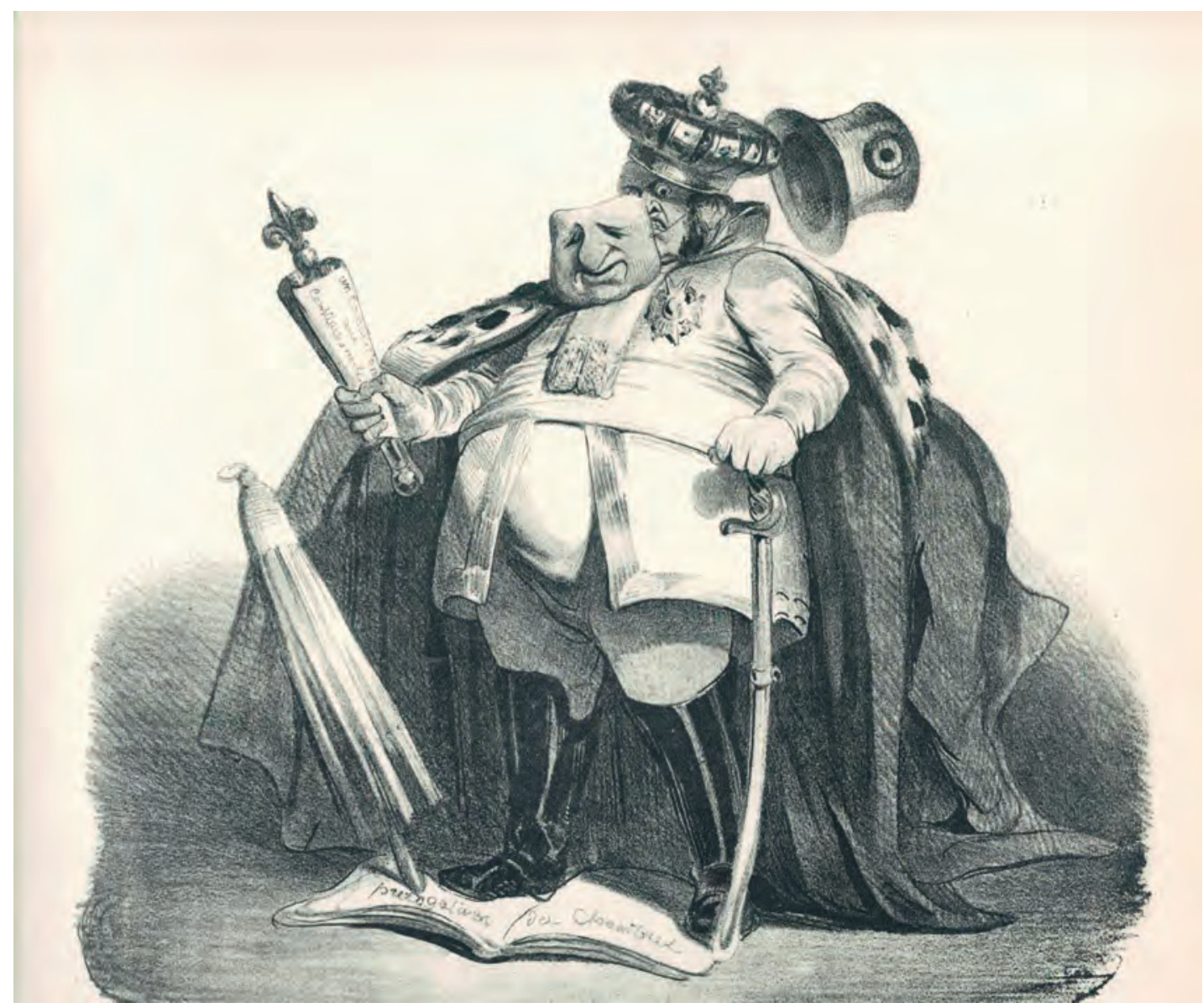

Fig. 13. Honoré Daumier (1808-1879), Principal acteur d'un imbroglio tragico-comique. (Principal Actor in a Tragicomic Farce). Lithography, 213 x $221 \mathrm{~mm}$. Le Charivari (29 March 1835). 
Although this passage almost reads like a caption for the above-mentioned cartoon, it is really its senior by about three years, which suggests an opposite line of reception in this case. While Daumier's cartoon only appeared in March 1835 in Philipon's second magazine Le Charivari, it can be assumed that it was inspired by Heine's French Affairs which, after having first been published in 1832, also appeared in a French translation entitled De la France in July 1833.

\section{Ekphrastic Caricature: Heine's Defence of Decamps's Turkish Patrol}

Although Heine's professed disapproval of the pear satires has turned out to be a mere subterfuge with regard to censorship, it is still open to question why he thought it necessary to defend Decamps's Turkish Patrol showing no obvious reference to the Citizen King against the accusation of caricature. It is essentially this passage that creates the impression that Heine's aversion to the phenomenon of caricature as such was genuine and sincere. Given Heine's obvious inclination to literary caricature and his spiritual and political affinity to the French political cartoonists, however, it seems appropriate to call his assertions yet again into doubt and, instead, to take a closer look at his description of the Turkish Patrol:

Er [der Hadji-Bey, V.F.] sitzt schwammbauchig hoch zu Roß, in aller Majestät seiner Insolenz, ein beleidigend arrogantes, unwissend stockfinsteres Gesicht, das von einem weißen Turban überschildet wird, in den Händen hält er das Scepter des absoluten Bastonadentums, und neben ihm, zu Fuß, laufen neun getreue Vollstrecker seines Willens quand même, hastige Kreaturen mit kurzen magern Beinen und fast thierischen Gesichtern, katzenhaft, ziegenböcklich, äffisch, ja, eins derselben bildet eine Mosaik von Hundeschnautze, Schweinsaugen, Eselsohren, Kalbslächeln und Hasenangst. In den Händen tragen sie nachläßige Waffen, Piken, Flinten, die Kolbe nach oben, auch Werkzeuge der Gerechtigkeitspflege, nemlich einen Spieß und ein Bündel Bambusstöcke. Da die Häuser, an denen der Zug vorbeykommt, kalkweiß sind und der Boden lehmig gelb ist, so macht es fast den Effekt eines chinesischen Schattenspiels, wenn man die dunkeln putzigen Figuren längs dem hellen Hintergrund und über einen hellen Vorgrund dahineilen sieht. Es ist lichte Abenddämmerung, und die seltsamen Schatten der magern Menschen- und Pferdebeine verstärken die barock magische Wirkung. Auch rennen die Kerls mit so drolligen Kabriolen, mit so unerhörten Sprüngen, auch das Pferd wirft die Beine so närrisch geschwinde, daß es halb auf dem Bauch zu kriechen und halb zu fliegen scheint (DHA 12.1, 23; The sponge-bellied Hadji-Bey is sitting high on his horse, in all the majesty of his insolence, with an offensively arrogant and ignorant gloomy face, shielded by 
a high white turban. In his hands he holds the sceptre of absolute Bastonadentum, and next to him, on foot, nine faithful executers of his will quand même, hasty creatures with short, skinny legs and almost beastly faces, catlike, goatish, ape-like - yes, one of them is a mosaic of dog's muzzle, pig's eyes, ass's ears, calf's smile and hare's fright. In their hands they carry carelessly weapons - pikes, guns, with the butt-ends uppermost, as well as the implements of justice, namely a lance and a bundle of bamboo sticks. As the houses before which the patrol passes are whitewashed and the soil is loamy yellow, it makes the impression of a Chinese shadow play when we see the dark droll figures hurrying along the light back- and foreground. It is clear twilight, and the grotesque shadows of the lean legs of men and horses increase the magical baroque effect. Moreover, the fellows run with such droll caprioles, such incredible leaps, even the horse throws up its legs with such foolish swiftness, that it seems to be halfcreeping on its belly and half-flying.)

A quick comparative glance at Decamps's painting reveals that what is only slightly deformed in the original becomes grotesquely exaggerated in Heine's ekphrasis: by associating the figures' facial features with those of various beasts, he conjures up fantastic fable-like creatures, some of which are hybrid monsters composed of several animal species. The optical dimension, however, is constantly transgressed by the ascription of mental attributes, such as arrogance, ignorance and servility. The suggestive comparison of the scene with a Chinese shadow-play moreover increases the contrast between light and dark areas and thus evokes a surreally bizarre scene in the mind of the reader. Heine's exaggerations become most evident in the insinuation of the figures' haggard limbs performing puppet-like movements as well as the horse's odd carriage, which brings to mind a mechanically driven marionette. This clearly caricatural ekphrasis suggests that it was not the technique of exaggeration or comic distortion from which Heine dissociates himself, but only the negatively connoted term "caricature" which he would not tolerate to be associated with Decamps's style. Not even the mixture of animal with human features (though being not so much part of the picture itself as of Heine's ekphrasis) is recognized as a classical means of caricature but merely termed a motive for humorous and extraordinary design ("Motiv zu ungewöhnlicher Darstellung"). As such, it had already been employed by the ancient Greeks and Romans who had taken delight in the invention of countless monsters ("unzähligen Mißgebilden") like satyrs, fauns or centaurs (DHA 21.1, 26). It is conspicuous that Heine generally seems to avoid the term caricature when commenting on comic distortion and resorts to substitute terms like "drollig" (droll, odd), "putzig" (funny, cute), "barock" (baroque) or "närrisch" (foolish), "Missgebilde" (monster) and "Persiflage" instead. In the further course of his discussion, Heine makes it definitely clear that his negative notion of caricature does not derive from 
the genre's tendency to deviate from nature. He himself confesses to his "supernaturalist" conviction that an artist's most important designs were not inspired by outward nature but rather individually conceived in his own mind. The sounds and words as well as the colours and shapes composers, poets and painters used in their works were thus not dependant on an object's real appearance and behaviour but only symbols by means of which they expressed their ideas (DHA 12.1, 24-25). The same is true for the hearer, reader or beholder of an artwork, as Heine has just demonstrated in his ekphrastic description. Instead of slavishly sticking to what is objectively depicted on the canvas, a recipient should listen to the subjective repercussions the artwork arouses in his own soul and allow them to bring forth wholly new ideas along with their appropriate original forms.

Another irritating aspect of Heine's defence of Decamps is that it is obviously conducted at the expense of the English satirist William Hogarth, who is accused not only of really having been a caricaturist but also of "Gemütszerrissenheit" and the resulting inability to paint harmonious pictures. In fact, Hogarth was a decidedly anti-neoclassicist artist who expressly refused to participate in the "tedious repetition of hackneyed, beaten subjects" from ancient mythology so common among his colleagues, and instead turned to the moral problems of the contemporary class society and their manifestations in everyday urban life (Hogarth 11-12; see also Donald, 164-69, and Bindman 5357, Faßhauer, “O, Hogarth" 170-72). Along with the novelist Henry Fielding, he endeavored to establish a new style of painting and writing devoted to the depravity, absurdity and ugliness of modern manners which had a comic and a tragic effect at the same time. Although he used the artistic means of comic exaggeration no less than Decamps, he had repeatedly protested against the accusation of painting caricatures (Kat. Caricature and its Role in Graphic Satire, 9; Rauser 43-44; Faßhauer, Wahre Charaktere 162-71). "Caricature" to him was a defamatory term denoting an absurdly grotesque image designed exclusively for amusement instead of moral instruction. He himself referred to his urban genre scenes as "modern moral subjects" and situated them halfway between the sublime and the grotesque genres (Hogarth 8), while his friend Fielding even more suggestively called them "comic history paintings" (Fielding 5). Correspondingly, Hogarth replaced the word "caricature" with the French term "outré" when signifying the comic exaggeration of facial and corporeal features. By means of this artifice, he detached the caricatural technique from its traditional association with grotesque contents and pointed out the possibility of its employment in more ambitious artworks (figure 14) (Faßhauer, Wahre Charaktere 163-67).

It is quite unlikely that Heine, having seen Hogarth's paintings during his stay in London in 1827 , should have missed the painter's predominant concern with imperfect reality. What arouses 


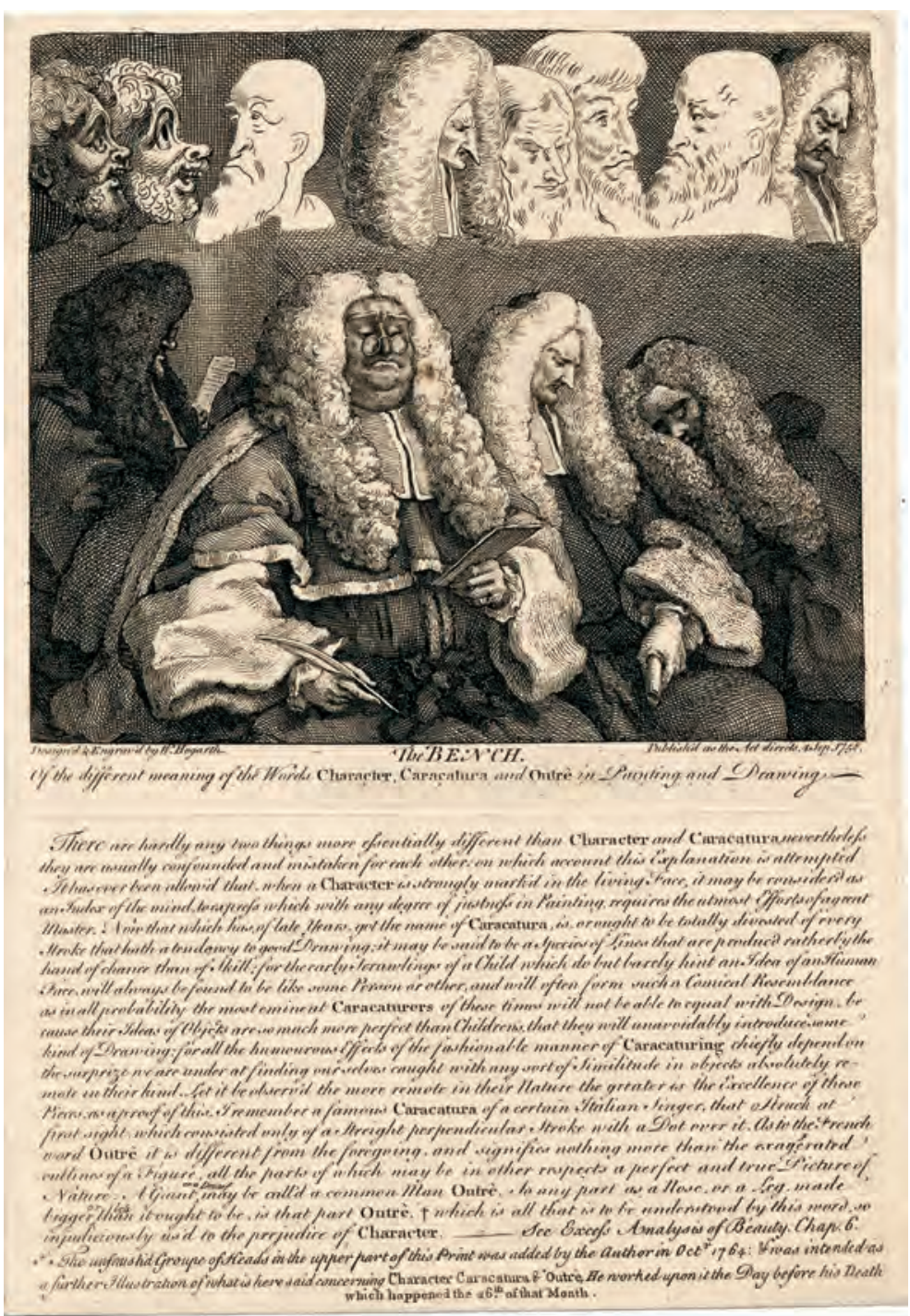

Fig. 14. William Hogarth (16971764), The Bench, 4th state, 1764 Engraving/Etching, 37,2 x 21,4 cm https://www.bl.uk/collection-items/ the-bench-by-william-hogarth 
suspicion is his diagnosis of Gemütszerrissenheit in the English satirist. Although in this context a negative connotation attaches to the term, we have already learned that, in Heine's mind, this mental condition inevitably resulted from the incompatibility of an artist's aspiration to beauty and objectivity and his subjective sense of the social, political or religious troubles surrounding him. This implicit hint to the artist's civil conscience is directly followed by the remark that Hogarth's pictures - apparently in contrast to Decamps's - displayed a turmoil (Emeute) of garish colors. This revolutionary metaphor suggests that this passage is not primarily intended as a stylistic or technical judgment but rather forms a transition to the final paragraph of Heine's discussion. In pointing to the sharp contrast between the unveiled Greek women in the background wearing wreaths of flowers and contrasting sharply with the group of Turkish armed men hurrying past, Heine hints at the Ottoman occupation of Greece and its struggle for political independence which was in process since 1821 (Zepf 104-05). With these allusions, he closes the circle of his discussion and refers back to his ekphrasis mentioning the Turkish police chief's haughty imperiousness as well as the fearful submissiveness of his henchmen carrying with them the weapons of oppression and the instruments of punishment and torture. In this way he leaves no doubt to his conviction that artworks could not sensibly be regarded separately from the historical circumstances that have occasioned them, as the art critic Heine demonstrates throughout his Salon review. After correlating all of the pictures he has chosen for discussion with the social, political and ideological problems of the contemporary world, in the end he explicitly dissociates himself from those egotistic neo-classicists who calmly indulged in their art enjoyment while the streets were sounding with the desperate cries of bitter poverty and public misery ("Nothschrey der erbitterten Armuth, und [...] des öffentlichen Elends", DHA 21.1, 46). In the very moment he was writing these lines, republicans who had just learned of the suppression of the Polish revolution ran frantically through the streets calling for the dismissal of the French ministry, thus forcing the deeply disturbed author to finish his art review prematurely (DHA 21.1, 44). What Heine experiences and shares here is nothing other than the Gemütszerrissenheit any politically conscientious artist would inescapably fall into in the face of such events. It therefore appears more than questionable if Heine's negative verdict on Hogarth's art should be taken literally (Häfner 114) or rather be interpreted as an appreciation of his social awareness and uprightness.

Similarly, Heine's art-theoretical reflections on subjective 'supernaturalism' and the 'somnambulist' conception of artistic means must not be misunderstood as a praise of an unworldly romanticist idealism (Häfner 107-14): As he explicitly states in the Romantische Schule (Romantic School) from 1836, art was not to be regarded as an independent second world ("als eine unabhängige zweite Welt"), turned away from the demands of that primary real world, to which precedence is 
due ("und von den Ansprüchen jener ersten wirklichen Welt, welcher doch der Vorrang gebührt, sich abzuwenden," DHA 8.1, 152-53). In Heine's usage of the term, the "supernaturalist" dissociation from reality does therefore not so much refer to the subject as to the stylistic execution of an artwork, which should not be guided by preconceived rules but by an artist's own subjective discretion. For this reason, he holds the caricatural exaggeration to be as legitimate an artistic means as dreamlike associations of heterogeneous ideas or forms, provided that they are in accord with the artist's idea and serve its adequate expression. As a matter of fact, the interplay between the idea and its execution should in Heine's opinion be the only aspect art criticism should be concerned with: "hat er die Mittel, seine Idee auszuführen? hat er die richtigen Mittel angewendet?" (DHA 21.1, 24; Has he the ability to carry out his idea? Has he applied the right means?). Accordingly, it is this perfect interplay between the painter's concept of despotism and unconditional obedience on the one hand and their artistic expression by means of distorted ugly features that Heine praises about Decamps's Smyrna street scene.

Besides, the fact that the picture struck the beholder as comical but still harmonious ("zwar komisch, aber doch harmonisch", DHA 12.1, 26) was essentially owing to the fact that the artist was a citizen of a free state. It seems rather odd that Heine should use this argument to prize Decamps's freedom of expression over Hogarth's, knowing that the United Kingdom had been a constitutional monarchy since 1688. It can therefore be assumed that he merely engages in a sham fight with his ally in order to advance their common concern. Like Hogarth one century before, Heine thus performs the detachment of comic exaggeration from its customary equation with the low and absurd and its resulting emancipation as an artistic means in its own right. 


\section{WORKS CITED}

BETZ, Albrecht. Ästhetik und Politik: Heinrich Heines Prosa, München: Hanser, 1971.

BINDMAN, David. Hogarth and his Times: Serious Comedy. London: British Museum Press, 1997.

BÖHM, Alexandra. “'Abbildungen des wirklichen Lebens' oder 'Hirngeburten'? Kontinuität und Wandel der Karikatur in Aufklärung und Vormärz". Der nahe Spiegel: Vormärz und Aufklärung. Eds. Wolfgang Bunzel, Norbert Otto Eke and Florian Vaßen (Vormärz-Studien XIV). Bielefeld: Aisthesis, 2008. 241-264.

BOSCH-ABELE, Susanne. La Caricature (1830-1835): Katalog und Kommentar. 2 vols. Weimar: VDG, 1997.

BUSCH, Wilhelm. Ut ôler Welt: Volksmärchen, Sagen, Volkslieder und Reime. Ed. Otto Nöldeke. München: Lothar Joachim, 1910.

Caricature and its Role in Graphic Satire: An Exhibition by The Department of Art, Brown University, at the Museum of Art, Rhode Island School of Design (April 7-May 9). Providence: Brown University, 1971.

Charte constitutionnelle du 14 août 1830, http://www.conseil-constitutionnel.fr/conseil-constitutionnel/francais/laconstitution/les-constitutions-de-la-france/charte-constitutionnelle-du-14-aout-1830.5104.html (accessed 21 December 2017).

DONALD, Diana. “This Truly Natural and Faithful Painter': Hogarth's Depiction of Modern Life”. Hogarth. Representing Nature's Machines. Eds. David Bindman, Frédéric Ogée and Peter Wagner. Manchester/New York: Manchester University Press, 2001. 163-191.

DÖRING, Jürgen. “'Die Presse ist vollkommen frei.' La Caricature und die Zensur”. La Caricature: Bildsatire in Frankreich 1830-1835 aus der Sammlung von Kritter. Ed. Gerd Unverfehrt. Göttingen: Kunstgeschichtliches Seminar der Universität, 1980. 27-39.

ESPAGNE, Michel. "Bilderverschiebung: Das politische Werk von Heinrich Heine und die Rolle der französischen Karikaturen”. Die Karikatur zwischen Republik und Zensur: Bildsatire in Frankreich 1830 bis 1880 - eine Sprache des Widerstands? Eds. Raimund Rütten et al. Marburg: Jonas, 1991. 159-166.

FASSHAUER, Vera. “'O, Hogarth, had I thy pencil!' Henry Fieldings literarische Karikaturen im Verhältnis zu den grafischen Satiren William Hogarths." Literatur und Malerei (Literatura-Konteksty 3). Eds. Joanna Godlewicz-Adamiec, Paweł Piszczatowski, Tomasz Szybisty, Bruno Arich-Gerz and Angelika Schneider. Kraków/Warszawa: Imedius, 2018. 201-215.

-. Wahre Charaktere, gute Karikaturen, schöne Ungeheuer: Zur Poetik des Hässlichen im 18. Jahrhundert (Jenaer Germanistische Forschungen. Neue Folge, 38). Heidelberg: Winter, 2016.

FIELDING, Henry. The History of the Adventures of Joseph Andrews and His Friend Mr. Abraham Adams. Written in Imitation of The Manner of Cervantes, Author of Don Quixote, and An Apology for the Life of Mrs. Shamela Andrews. Ed. Douglas Brooks. London: Oxford University Press, 1970. 
HÄFNER, Ralph. Die Weisheit des Silen: Heinrich Heine und die Kritik des Lebens (Spectrum Literaturwissenschaft 7). Berlin; New York: de Gruyter, 2006.

HEINE, Heinrich. Historisch-kritische Gesamtausgabe der Werke (Düsseldorfer Heine-Ausgabe, DHA). Ed. Manfred Windfuhr. Hamburg: Hoffmann und Campe, 1980. 15 vols. http://www.hhp.unitrier.de/Projekte/HHP/werke (accessed 21 December 2017).

- The works. Transl. from German Charles Godfrey Leland. London: William Heinemann, 1893. Vols. IV and VII.

HOFMANN, Werner. "Heine und die Malerei der Zukunft.” Heine-Jahrbuch 20 (1981): 72-89.

HOGARTH, William. Anecdotes of William Hogarth, Written by Himself. With Essays on his Life and Genius, and Criticisms on his Works. Selected from Walpole, Gilpin, J. Ireland, Lamb, Phillips, and Others. London: J.B. Nichols and Son, 1833.

HOHENDAHL, Peter Uwe. "The Emblematic Reader: Heine and French Painting". Paintings on the Move: Heinrich Heine and the Visual Arts. Ed. Susanne Zantop. Lincoln; London: University of Nebraska Press, 1989. 9-29.

HÖHN, Gerhard. Heine-Handbuch: Zeit, Person, Werk. Stuttgart: Metzler, 2004.

HÖMBERG, Walter. Zeitgeist und Ideenschmuggel: Die Kommunikationsstrategie des Jungen Deutschland. Stuttgart: Metzler, 1975.

LELAND, Charles Godfrey. The works of Heinrich Heine: Translated from the German. London: William Heinemann, 1893. Vols. IV and VII.

PHILIPON, Charles (ed). La Caricature politique, morale, religieuse, littéraire et scénique. Paris: Aubert, 183043. http://gallica.bnf.fr/ark:/12148/cb344523348/date (accessed 21 December 2017).

MORAWE, Bodo. "Daumiers 'Sujets', Blanquis Rede und der Citoyen Heine: Republikanischer Kairos und intermediales 'crossover' im Krisenjahr 1832". Heinrich Heine und die Kunstkritik seiner Zeit: Akten des Internationalen und interdisziplinären Kolloquiums Paris, 26-30. April 2006. Ed. Ralph Häfner. Heidelberg: Winter, 2010. 71-97.

-. Heines "Französische Zustände": Über die Fortschritte des Republikanismus und die anmarschierende Weltliteratur. Heidelberg: Winter, 1997.

PRAWER, Siegbert S. Heine's Jewish Comedy: A Study of his Portraits of Jews and Judaism. Oxford: Clarendon, 1983.

PREISENDANZ, Wolfgang. Heinrich Heine: Werkstrukturen und Epochenbezüge. München: Fink, 1983.

RADLIK, Ute. "Heine in der Zensur der Restaurationsepoche". Zur Literatur der Restaurationsepoche 18151848. Eds. Jost Hermand and Manfred Windfuhr. Stuttgart: Metzler, 1970. 460-489.

RAUSER, Amelia. Caricature Unmasked: Irony, Authenticity and Individualism in Eighteenth-Century English Prints. Newark: University of Delaware Press, 2008. 
REED, Terence James. "History in Nutshells: Heine as a Cartoonist." Heinrich Heine and the Occident: Multiple Identities, Multiple Receptions. Eds. Peter Uwe Hohendahl and Sander L. Gilman. Lincoln and London: University of Nebraska Press, 1991. 163-186.

ROSE, Margaret A. "Karikatur und Parodie: Private und öffentliche Versteckspiele in der deutschen Kunst um 1850”. Europäische Karikaturen im Vor- und Nachmärz. Eds. Hubertus Fischer and Florian Vaßen. Bielefeld: Aisthesis, 2006. 111-140.

ROSENKRANZ, Karl. Zur Geschichte der deutschen Literatur. Königsberg: Bornträger, 1836.

RUGE, Arnold. Neue Vorschule der Ästhetik: Das Komische mit einem komischen Anhange. Halle: Buchhandlung des Waisenhauses, 1837.

RÜTTEN, Raimund. "Die republikanische Opposition und die Zensur." In Die Karikatur zwischen Republik und Zensur: Bildsatire in Frankreich 1830 bis 1880 - eine Sprache des Widerstands? Eds. Raimund Rütten et al. Marburg: Jonas, 1991. 83-90.

THOMKE, Hellmut. "Heine und Grandville". Heine-Jahrbuch 17 (1978): 126-151.

UNVERFEHRT, Gerd. "Karikatur: Zur Geschichte eines Begriffs". Bild als Waffe: Mittel und Motive der Karikatur in fünf Jahrhunderten. Eds. Gerhard Langemeyer and Gerd Unverfehrt. München: Prestel, 1984. 345-354.

-. "La Caricature: Anmerkungen zur Geschichte einer Zeitschrift". La Caricature: Bildsatire in Frankreich 1830-1835 aus der Sammlung von Kritter. Ed. Gerd Unverfehrt. Göttingen: Kunstgeschichtliches Seminar der Universität, 1980. 9-14.

VISCHER, Friedrich Theodor. Ueber das Erhabene und Komische: Ein Beitrag zu der Philosophie des Schönen. Stuttgart: Imle \& Krauß, 1837.

-. Aesthetik oder Wissenschaft des Schönen: Zum Gebrauche für Vorlesungen. Ed. Robert Vischer. München: Meyer \& Jessen, 1922-1923. 6 vols.

VOISINE, Jacques. "Heine als Porträtist in der Lutezia." Internationaler Heine-Kongreß 1972. Ed. Manfred Windfuhr. Hamburg: Hoffmann \& Campe, 1973. 219-226.

ZANTOP, Susanne. "Introduction”. Paintings on the Move: Heinrich Heine and the Visual Arts. Ed. Susanne Zantop. Lincoln and London: University of Nebraska Press, 1989. 1-7.

ZEPF, Irmgard. Heinrich Heines Gemäldebericht zum Salon 1831: Denkbilder. Eine Untersuchung der Schrift "Französische Maler". München: Wilhelm Fink, 1980.

ZIEGLER, Edda. Literarische Zensur in Deutschland 1819-1848: Materialien, Kommentare. München: Allitera, 2006. 